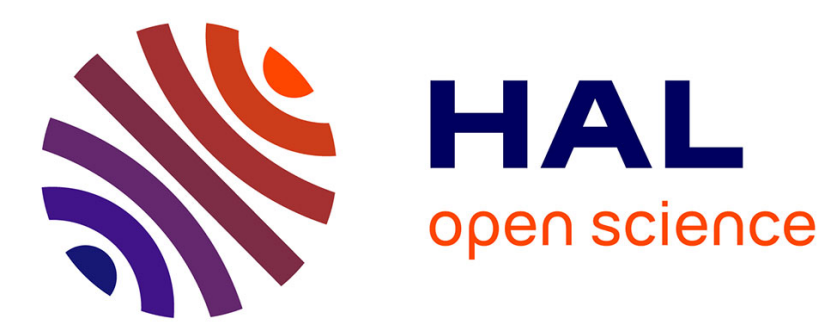

\title{
Using the present tense to talk about irreality
}

\author{
Isabel Repiso
}

\section{To cite this version:}

Isabel Repiso. Using the present tense to talk about irreality. Martin Howard and Pascale Leclercq. Tense-Aspect-Modality in a Second Language. Contemporary Perspectives, John Benjamins, pp.213 - 252, 2017, 10.1075/sibil.50.08rep . halshs-03330848v1

\section{HAL Id: halshs-03330848 https://shs.hal.science/halshs-03330848v1}

Submitted on 3 Sep 2021 (v1), last revised 6 Sep 2021 (v2)

HAL is a multi-disciplinary open access archive for the deposit and dissemination of scientific research documents, whether they are published or not. The documents may come from teaching and research institutions in France or abroad, or from public or private research centers.
L'archive ouverte pluridisciplinaire HAL, est destinée au dépôt et à la diffusion de documents scientifiques de niveau recherche, publiés ou non, émanant des établissements d'enseignement et de recherche français ou étrangers, des laboratoires publics ou privés. 


\section{John Benjamins Publishing Company}

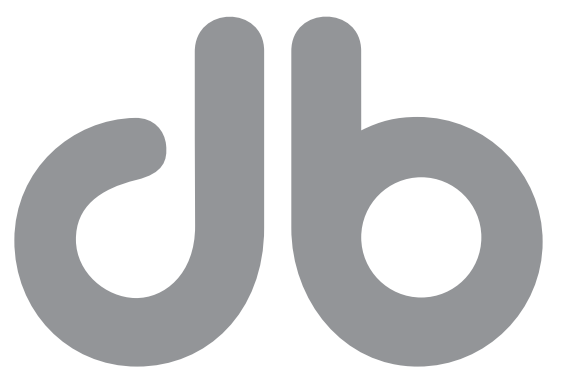

This is a contribution from Tense-Aspect-Modality in a Second Language. Contemporary perspectives.

Edited by Martin Howard and Pascale Leclercq.

(c) 2017. John Benjamins Publishing Company

This electronic file may not be altered in any way.

The author(s) of this article is/are permitted to use this PDF file to generate printed copies to be used by way of offprints, for their personal use only.

Permission is granted by the publishers to post this file on a closed server which is accessible to members (students and staff) only of the author's/s' institute, it is not permitted to post this PDF on the open internet.

For any other use of this material prior written permission should be obtained from the publishers or through the Copyright Clearance Center (for USA: www.copyright.com). Please contact rights@benjamins.nl or consult our website: www.benjamins.com Tables of Contents, abstracts and guidelines are available at www.benjamins.com 


\title{
Using the present tense to talk about irreality Differences and similarities across the L2 grammars of Italian learners of French
}

\author{
Isabel Repiso \\ University of Haute-Alsace
}

Counterfactuality is a semantic subdomain of irreality (Pietrandrea 2010) which results from the comparison of reality to an imagined view of what might have been (Kahneman \& Tversky 1982). Previous studies have shown that simple clauses containing the conditional tense are frequently used by native speakers of French to express irreality (Hellberg 1971; Repiso 2013). This use corresponds to the grammatical description of the conditional tense, which is said to mark the posteriority of a process whose realization is deferred to certain hypothetical conditions (Charaudeau 1992). In contrast to the conditional, this study explores the use of the present indicative which our learners predominantly used in the semantic domain of counterfactuality. A heterogeneous group of 23 Italian learners of French completed a mutation task and a predictive task. Their responses were transcribed and analyzed both quantitatively and qualitatively. At a general level, indicative tenses other than the conditional were significantly overused in the corpus as a whole. This type of response was usually structured by coordinated clauses, similar to linear narrations. However, behind this general pattern, we found three sets of grammatical regularities which allowed us to distinguish the learners: a) an overuse by some learners of bare present forms as well as the periphrastic future form 'Aller (to go) + Infinitive'; b) a broader repertoire characterizing other learners who combine the present or the imparfait (imperfective) and some forms of the conditional; and c) a dominant use among some learners of the conditional over other indicative tenses. Our results suggest that the present tense is frequently used by Italian learners in the construction of counterfactual scenarios. This may be explained because of (i) a stylistic preference in the case of those learners able to align their productions to the native pattern and (ii) the under-developed grammars of those learners who do not use conditional forms. 


\section{Introduction}

The present tense and the imparfait in French are traditionally depicted as native speaker grammatical devices encoding states-of-affairs whose actualization is effective at the moment of the topic time or in the past (Chevalier et al. 1964; Charaudeau 1992; Riegel et al. 1994). In Second Language Acquisition (SLA), evidence has been provided to similarly demonstrate the use of the present tense to express states-of-affairs occurring in the past (Harley 1992). Such use has usually been described as a feature reflecting the learner's developmental grammar (Bartning 1997). On the other hand, the use of the present tense as a non-canonical way of expressing past events in a second language (L2) remains controversial if we look at native speakers' usage. Previous studies of native speakers of French have confirmed the spontaneous use of the present tense in oral production tasks to retell past events (Carroll et al. 2008; Dimroth et al. 2010) and fictional events (Krifka 2012). Interestingly, the latter is not consistent with the semantic domain prescribed by grammarians for the indicative mood, which usually frames a given state-of-affairs within the realm of reality (Riegel et al. 1994).

The non-canonical use of the present tense has generally not been studied outside narrative texts and it has so far not been the subject of investigation in counterfactual semantic contexts. The objective of the present study is to explain the use of the indicative tenses traditionally associated with actualized states-of-affairs in French, namely the present indicative and the imparfait, to express irreality by a heterogeneous group of Italian learners. We will argue that the non-canonical use of the indicative mood is not only related to sociolinguistic factors having an impact on the learner's proficiency, such as immersion in the target language environment or an instructed context, but also to a strategy by which the speakers frame narrative texts in their first language (L1).

Our chapter is organized in seven sections. In the next one, Section 2, we explain how Irrealis is linked to the expression of temporality and we offer an overview of the tenses used in French and Italian to mark counterfactuality. In the following section, we summarize some conclusions from previous SLA studies that have analyzed the expression of counterfactuality. Our research questions are presented in the fourth section. Subsequently, we present the sociolinguistic profiles of our learners as well as the two tasks that they completed. The sixth and the seventh sections present the quantitative and qualitative results, respectively. In the eighth section, we offer some empirical arguments to reconsider the noncanonical uses of the indicative mood as a stylistic licence when retelling actualized states-of-affairs or speaking about counterfactual scenarios. Finally, we sum up our conclusions. 


\section{The notion of counterfactuality}

Irrealis has traditionally been defined as a subdomain of the hypothetical system. The hypothetical system has been characterized by a wide range of if- clauses going from potentiality to irreality (Comrie 1986; Harris 1986). Depending on the verbal morphology of a given if-clause, the semantic value of the proposition may refer to the unreal non-past (1) or to the unreal past (2).

(1) If he came, he would see me (but he won't)

(2) If he had come, he would have seen me (but he didn't)

In the unreal non-past, the condition if $A$ is not realized at the topic time, nor has it been previously, but it may be in the future, whereas in the unreal past, the condition if $A$ is not realized at the topic time, nor has it been previously and it will not be in the future (Renzi \& Salvi 1991; Riegel et al. 2001; Grevisse \& Goosse 2008; Real Academia Española 2009). In addition to this categorization, there is the distinction between the potential non-past (3) and the potential past (4).

(3) If he were to come, he would see me (he probably won't but he might)

(4) If he were to have come, he would have seen me (maybe he did, maybe he didn't)

This overlapping system combining temporal traits, non-past versus past, and actualization traits, unreal versus potential, has served to explain the development of conditional constructions from Latin to modern Romance languages (Harris 1986: 268). However, such a categorization does not allow a direct distinction between the potential past (4) and the unreal past (2). This is because the ultimate factor in distinguishing the unreal from the potential is the speaker's state of knowledge. Irreality has been defined as a super-category covering three subdomains: counterfactuality, the non-exclusion-of-factuality and non-referentiality (Pietrandrea 2010). Since counterfactuality results from the comparison of reality to an imagined view of what might have been (Kahneman \& Tversky 1982), the certainty of the speaker about the non-realization of the propositional content (Verstraete 2005) seems to be a sine qua non characteristic. ${ }^{1}$ The present study focuses on the non-canonical use of the present tense to express counterfactual scenarios in L2

\footnotetext{
1. This idea is at the center of the debate on the appropriateness of the term 'future counterfactuals. Because the future is due to take place sometime after the topic time, it is considered to be a less well known domain compared to the present or the past (Iatridou 2000; Van linden \& Verstraete 2008). This is why some authors consider it inaccurate to talk about 'future counterfactuals?
} 
French. Our results are based on a well-defined semantic domain which is characterized by (i) the ascription of the learner's responses to the unreal past frame and (ii) the certainty of the speaker about the non-actualization of what has been said.

Even though our study focuses on the present indicative, the target forms to refer to other possible worlds in French are those of the conditional tenses. As we previously noted, the conditional marks the posteriority of a process whose realization is deferred to certain hypothetical conditions (Charaudeau 1992). This grammatical description reflects the usage-based data observed in French in oral and written texts (Hellberg 1971). Modal and volition verbs pouvoir, devoir, vouloir, souhaiter, aimer (may, have to, would, wish, love) have also been described as frequent markers of non-factual scenarios when conjugated in the past conditional (Fauconnier 1984).

(5) J'aurais fait le tour de France sans bouffer

(Hellberg 1971: 107) I would have done the Tour of France without eating

(6) Jean aurait pu être quelqu'un d'autre

(Fauconnier 1984: 144) Jean could have been anybody else

In Italian, counterfactuality has been described as a complex semantic effect emerging from the interaction between the pluperfect subjunctive and the past conditional, the propositional content of the if- clause and the linguistic and extralinguistic context (Renzi \& Salvi 1991: 758). However, a colloquial variant is possible using the indicative imperfetto in both the main and subordinated clause (8). This use is quite extensive in spoken Italian. The main difference between ifclauses in French and Italian relates to the subordinate clause; French requires the indicative imparfait, whereas Italian requires a subjunctive. Potential uses of the conditional in the subordinate if- clause are considered ungrammatical in both languages. Conversely, the conditional is the canonical tense in the main clause for both languages, as can be observed by comparing example (7) to example (5).

(7) Se fossi venuto alla festa, ti saresti divertito moltissimo (Renzi \& Salvi 1991: 754)

If you had come to the party, you would have had so much fun

(8) Se venivi alla festa, ti divertivi un sacco

(Renzi \& Salvi 1991: 754)

If you came to the party, you would have had a lot of fun

Previous research on the acquisition of L2 Italian has shown the complex input to which learners are exposed in the case of conditional constructions (Bernini 1994, 1995). This author explains that native speakers of Italian express irreality through a wider range of tenses than the canonical subjunctive forms. The next example is taken from Bernini (1994), based on a conversation between a native Italian 
speaker and a 20 year-old Eritrean immigrant whose L1 is Tigrinya and was in Italy for one month when first recorded:

(9) ${ }^{\star} \mathrm{INT}: \quad$ ma, se voi vi trovaste [...] nella stessa situazione.

${ }^{\star}$ INT: che cosa fareste?

${ }^{*}$ INT: mettiamo che voi arrivate in campeggio.

${ }^{*}$ INT: volete affittare una roulotte, e non trovate piu i documenti.

${ }^{*} \mathrm{INT}$ : cosa fareste?

*SBJ: dobbiamo tornare + a prendere.

${ }^{\star}$ INT: but, what if you were [...] in the same situation.

${ }^{\star}$ INT: what would you do?

${ }^{\star}$ INT: let's say that you arrive at a camping.

${ }^{\star}$ INT: you want to rent a caravan, but you don't find the papers.

*INT: what would you do?

${ }^{\star}$ SBJ: $\quad$ we must go back and get them.

(Bernini 1994: 274, 1995: 312)

The example above illustrates some of the constructions and tenses used by native Italians to denote a non-factual state-of-affairs beyond the canonical subjunctive (used in the first line). In the third line, the native speaker expresses a non-factual scenario by mettiamo che (let's say that) followed by three present indicatives (arrivate, volete, trovate, [you] arrive, want, find) that work as subjunctives from a pragmatic viewpoint. In fact, the present tense is used by the native speaker to set three conditions triggering a possible world different from the actual one. At the end, (s)he addresses an overt question marked by the conditional tense.

In the past, the conditional has been considered as a mood in its own right. Proponents of this idea considered the conditional as the mode of hypothetical and unreal worlds, in opposition to the future, which was considered the mood of probability and eventuality (Riegel et al. 1994). In the present chapter, we consider the conditional within the indicative mood, whereby the conditional is a sort of future within the past (Grevisse \& Goosse 2012) and thus, the past conditional expresses a temporal value of posteriority in the past (Barceló \& Bres 2006), like in Figure 1. From a semantic viewpoint, counterfactuality combines the apparently contradictory features of potentiality and non-actualization (Verstraete 2005). Counterfactual sentences express something that was desired but did not happen, or an action that was intended but not carried out in the end. Verstraete (2005) refers to them as implicatures of past potentiality. The way in which Romance languages like French or Spanish denote this past potentiality is by means of conditional tenses. Conditional tenses in these languages are formed in general by the suffixes from the imparfait and imperfecto (-ais, -ais, -ait, -ions, -iez, -aient in French; -ía, -ías, -ía, -íamos, -íais, -ían in Spanish) preceded by the morpheme $-r$, 
which normally marks the future. Past tense morphology is in fact a component of counterfactual morphology (Iatridou 2000), along with modal markers (Van linden \& Verstraete 2008).

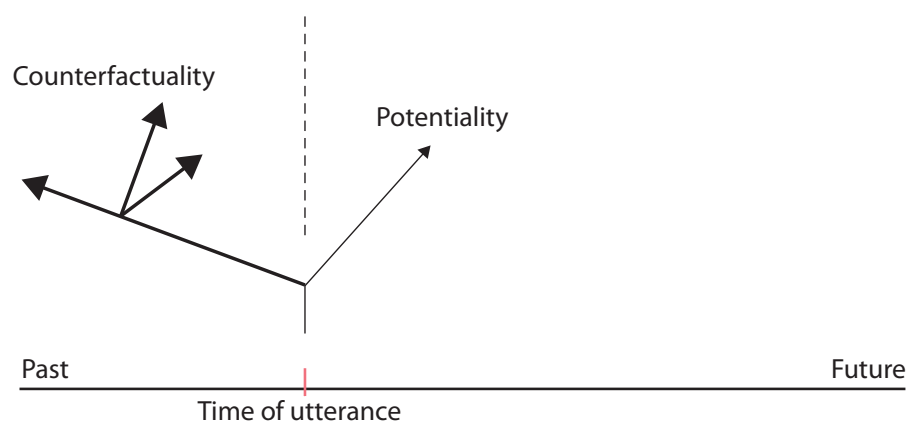

Figure 1. Graphical representation of other possible worlds

\section{Counterfactuality in second language acquisition}

Not much is known in SLA about how learners mark time in counterfactual contexts. To date, the description of hypothetical and irrealis scenarios has generally been restricted to conditional constructions if $P$ (then) $Q$ (Bates 1976; Bloom 1981; Reilly 1982; Au 1983; Akatsuka \& Clancy 1993; Bernini 1994; Chini 1995; Katis 1996; Schouten 2000; Yeh \& Gentner 2005), and only a few studies have analyzed them in relation to a broader set of constructions (Hellberg 1971; Bowerman 1986; Van linden \& Verstraete 2008; Repiso 2013). The present tense has been found among the grammatical devices by which native speakers mark time in fictitious discourse (Klein 2009; Krifka 2012). This use matches the description provided by grammarians of the 'historical present', in which the present indicative refers to narrations anchored in the past or to fictional worlds (Riegel et al. 2014: 533). ${ }^{2}$

\footnotetext{
2. Whereas the French conditional is presented as a tense related either to temporal or modal meanings, the present indicative is generally expected for contexts in which the time of the situation is more or less simultaneous to the utterance time. However, it is commonly assumed that the use of the present indicative does not always refer to the utterance time and might denote the past or the future. This is possible because of the presence of temporal adverbs or the listener's contextual knowledge (Riegel et al. 2014: 532). The indicative mood is generally described in French as a way to mark the actualization of a process (Riegel et al. 1994, Chevalier et al. 1964) or a view of effective realization (Charaudeau 1992). Conversely, the subjunctive mood in French frames a process in other possible worlds (Riegel et al. 1994), accounts for the potential or eventual realization of a process (Charaudeau 1992) or for the speaker's epistemic modality (Chevalier et al. 1964).
} 
In the absence of descriptions explaining the present indicative in counterfactual readings, one might intuitively assume that its use is far from canonical. Our data will confirm or dismiss this assumption. So far, the descriptions regarding the use of the present tense in SLA have been linked to the post-basic learner variety. ${ }^{3}$ At this developmental stage, the L2 learner usually produces the present tense as a non-marked morphological means to express the past (Bartning 1997) and counterfactual states-of-affairs (Bernini 1994). In the latter case, the following example in (10) is indicative of such usage, based on Bernini's (1994) study of a 29 year-old Moroccan migrant whose first languages were Arabic and French, and who had lived in Italy for two years when he was recorded:

(10) ${ }^{\star}$ INT: se lui fosse stato veramente appogiato all'albero [...], che cosa sarebbe successo?

*SBJ: l'albero cade cosi

*INT: if he really had been leant against the tree [...], what would have happened?

*SBJ: the tree falls like this

(Bernini 1994: 281)

A further line of inquiry concerning the use of the present in L2 French relates to the use of the third-person plural form of the present indicative. Such forms seem to be particularly challenging, with erratic forms such as ils ${ }^{*}$ prend (they ${ }^{\star}$ takes) co-occurring with some correct ones, ils prennent (they take) in the learner's language system (Bartning \& Schlyter 2004). This type of error continues to be found in advanced learners for some irregular verbs like sortir (to go out) (Bartning \& Schlyter 2004). Notwithstanding such lines of inquiry, the exploitation of the present indicative in more developed learner varieties has rarely been the focus of attention in research on the L2 acquisition of French. Against this background, the present study aims to explain the non-canonical production of the present tense to encode counterfactuality in L2 French by a heterogeneous group of Italian learners.

With regard to the use of the conditional tense in L2 French, this form has been mostly described in the case of instructed learners. For example, the integration of conditional forms has been detected relatively late in the developmental trajectory of Swedish learners having completed between three and six years of university studies and having lived in France for less than 18 months (Bartning 1997). Exposure to naturalistic input seems to be a crucial factor in the integration

3. A learner variety is "a more or less realistic picture of the set of grammatical regularities in the language behavior of certain people under certain conditions" (Klein \& Dittmar, 1979: 35). Among the characteristics of the basic variety, Klein \& Perdue (1997) have described nominal utterance structures, non-finite utterance organization and the absence of complex subordination. 
of this tense in hypothetical contexts, as shown by Howard (2012) and Housen et al. (2006). In particular, immersion in France had a positive impact on a group of English-speaking university learners compared to another group which was taught in the foreign language classroom (Howard 2012). This advantage was notable in the verbal morphology within if-clauses and in the expression of nonfactual scenarios. This result is coherent with the benefits observed by Housen et al. (2006) in a group of Belgian teenage learners who used French not only in the classroom but also in their daily life at home, unlike their counterparts who only used French in a classroom context. These learners produced conditional forms in epistemic comments as well as in hypothetical accounts, as native speakers do. In the light of these surveys, one might wonder about how to present the conditional tense in the foreign language classroom. In this regard, Hendrix et al. (2001) show that explicit teaching appeared not to be sufficient to enable the production of conditional forms in semi-spontaneous contexts for a group of Dutch-speaking learners.

\section{Research questions}

This study's research questions are as follows:

- In the expression of counterfactuality, what is the role of the present indicative in the interlanguage grammars of Italian learners of French who also produce conditional forms?

- What are the explanatory factors accounting for the preference of the present indicative over the conditional in the expression of counterfactuality?

- Do typological factors involving tense have an impact on the learner's grammar in the case of L1 Italian learners of French? In other words, do the salient forms characteristic of Italian somehow influence the production of verb morphology in L2 French?

- Does verbal morphology provide a reliable clue to the learner's proficiency level?

The last three questions are crucial to our contribution to the present volume. Both typological and developmental factors will be taken into consideration for two different purposes. Typological factors between French and Italian should allow us to test an effect for transfer. On the other hand, we will try to see beyond the general pattern of overusing the present tense in counterfactual contexts by describing some developmental features of the learners' grammars. 


\section{Method}

The data we will discuss come from a cross-sectional study of 30 Italian learners of French and 30 native French speakers. The learner group completed an oral mutation task and a predictive task in their L2 and L1, in random order (cf. Appendix 1). The data collection took place in France, in the Aix-Marseille area, and partially in Nijmegen, The Netherlands. ${ }^{4}$ The learners' sociolinguistic information was collected through written questionnaires immediately before the recording. Two factors were measured: the time they had lived in France and the amount of instruction in French. We will henceforth refer to these factors as immersion and studies of French as a foreign language (FFL), respectively. Since some of our learners were residing in the Netherlands, the immersion variable only concerns the period of time that they had lived in France prior to the recording.

\subsection{Participants}

The learner group was composed of 20 women and 10 men aged between 20 and 56 years. They had all completed university studies. This group studied FFL for an average of 4.6 years in an instructed context and had lived in France for an average of 1.5 years at the time of the data collection. ${ }^{5}$ Fourteen participants came from southern Italy (eight from Campania, three from Basilicata, one from Calabria, one from Sicily and one from Apulia), thirteen from northern Italy (nine from Veneto, three from Liguria and one from Lombardia) and three from the centre (one from Tuscany, one from Emilia-Romagna and one from Lazio). At the time of data collection, 22 learners had lived in France for a period equal to or less than 12 months, ${ }^{6}$ four had studied FFL for a period equal to or less than 12 months ${ }^{7}$ and four had never studied French before spending some time in France. ${ }^{8}$ Taking into consideration these variables, the less experienced learners appear to be subjects $14,15,17,18,22$ and 23.

The control group was composed of 20 women and 10 men between 17 and 57 years old. Like the learner group, they came from a university background. 20 of

4. Three out of 30 learners and three out of 30 French native speakers were recorded in Nijmegen (Italian subjects 17, 18, 19 and French subjects 12, 14, 15).

5. The mean regarding the studies of FFL has been calculated over 29 subjects (subject 12 was excluded because he presented more than 40 years, which might have biased the group's mean).

6. Subjects $1,3,4,6,7,8,9,10,11,14,15,17,18,21,22,23,24,26,27,28,29,30$.

7. Subjects $14,18,19,23$.

8. Subjects 14, 15, 17, 22.

(C) 2017. John Benjamins Publishing Company

All rights reserved 
them came from southeast France, (Provence-Alpes-Côte d'Azur), five from Paris, two from northern France (Normandy and Nord-Pas-de-Calais), two from Eastern

Table 1. Italian learners of French

\begin{tabular}{|c|c|c|c|c|c|c|c|}
\hline Subject & L1 & Sex & Age & $\begin{array}{l}\text { Geographical } \\
\text { provenance }\end{array}$ & $\begin{array}{c}\text { Time of FFL } \\
\text { studies }\end{array}$ & $\begin{array}{c}\text { Time of } \\
\text { immersion }\end{array}$ & $\begin{array}{c}\text { Random } \\
\text { order }\end{array}$ \\
\hline 1 & Italian & $\mathrm{M}$ & 30 & Campania & 10 years & 1 year & FFL-L1 \\
\hline 2 & Italian & $\mathrm{F}$ & 29 & Liguria & 7 years & 2 years & L1-FFL \\
\hline 3 & Italian & $\mathrm{F}$ & 24 & Veneto & 8 years & 1 year & L1-FFL \\
\hline 4 & Italian & $\mathrm{M}$ & 24 & Veneto & 10 years & 1 year & L1-FFL \\
\hline 5 & Italian & $\mathrm{F}$ & 28 & Liguria & 18 years & 8 years & FFL-L1 \\
\hline 6 & Italian & $\mathrm{F}$ & 24 & Veneto & 5 years & 5 months & L1-FFL \\
\hline 7 & Italian & $\mathrm{M}$ & 26 & Basilicata & 4 years & 1 year & L1-FFL \\
\hline 8 & Italian & $\mathrm{F}$ & 25 & Veneto & 8 years & 4 months & L1-FFL \\
\hline 9 & Italian & $\mathrm{F}$ & 26 & Tuscany & 4 years & 4 months & FFL-L1 \\
\hline 10 & Italian & $\mathrm{F}$ & 20 & Campania & 5 years & 5 months & FFL-L1 \\
\hline 11 & Italian & $\mathrm{F}$ & 23 & Liguria & 3 years & 3 months & L1-FFL \\
\hline 12 & Italian & $\mathrm{M}$ & 56 & Sicily & 46 years & 7 years & FFL-L1 \\
\hline 13 & Italian & $\mathrm{F}$ & 32 & Calabria & 0 & 4 years & L1-FFL \\
\hline 14 & Italian & $\mathrm{M}$ & 22 & Campania & 6 months & 3 months & FFL-L1 \\
\hline 15 & Italian & $\mathrm{F}$ & 26 & Apulia & 0 & 1 year & FFL-L1 \\
\hline 16 & Italian & $\mathrm{F}$ & 34 & Veneto & 6 years & 5.5 years & L1-FFL \\
\hline 17 & Italian & $\mathrm{F}$ & 34 & Campania & 0 & 1 year & L1-FFL \\
\hline 18 & Italian & $\mathrm{F}$ & 23 & Veneto & 6 months & 1 month & L1-FFL \\
\hline 19 & Italian & $\mathrm{M}$ & 37 & Veneto & 2 months & 3 years & FFL-L1 \\
\hline 20 & Italian & $\mathrm{F}$ & 28 & Campania & 5 years & 6 months & FFL-L1 \\
\hline 21 & Italian & $\mathrm{F}$ & 21 & Campania & 2 years & 2 months & L1-FFL \\
\hline 22 & Italian & $\mathrm{F}$ & 21 & Lombardy & 0 & 1.5 months & L1-FFL \\
\hline 23 & Italian & $\mathrm{M}$ & 21 & Veneto & 1 year & 2 months & FFL-L1 \\
\hline 24 & Italian & $\mathrm{F}$ & 20 & Campania & 3 years & 2 months & FFL-L1 \\
\hline 25 & Italian & $\mathrm{F}$ & 33 & Campania & 5 years & 7 years & FFL-L1 \\
\hline 26 & Italian & $\mathrm{F}$ & 20 & Emilia-Romagna & 7 years & 2 months & L1-FFL \\
\hline 27 & Italian & $\mathrm{M}$ & 25 & Basilicata & 8 years & 3 months & FFL-L1 \\
\hline 28 & Italian & $\mathrm{M}$ & 21 & Basilicata & 8 years & 2 months & FFL-L1 \\
\hline 29 & Italian & $\mathrm{M}$ & 21 & Lazio & 3 years & 2 months & L1-FFL \\
\hline 30 & Italian & $\mathrm{F}$ & 26 & Veneto & 5 years & 1 year & L1-FFL \\
\hline
\end{tabular}


France (Burgundy and Franche-Comté) and one from Canada (Quebec). Details about the individual learners and control group are presented in Tables 1 and 2.

Table 2. French control group

\begin{tabular}{|c|c|c|c|c|}
\hline Subject & L1 & Sex & Age & $\begin{array}{l}\text { Geographical } \\
\text { provenance }\end{array}$ \\
\hline 1 & French & $\mathrm{F}$ & 21 & Southeast France \\
\hline 2 & French & F & 22 & Southeast France \\
\hline 3 & French & $\mathrm{F}$ & 21 & Southeast France \\
\hline 4 & French & $\mathrm{F}$ & 56 & Paris \\
\hline 5 & French & $\mathrm{F}$ & 20 & Southeast France \\
\hline 6 & French & $\mathrm{F}$ & 25 & Southeast France \\
\hline 7 & French & $\mathrm{F}$ & 20 & Southeast France \\
\hline 8 & French & $\mathrm{F}$ & 55 & Southeast France \\
\hline 9 & French & M & 26 & Northern France \\
\hline 10 & French & $\mathrm{F}$ & 26 & Southeast France \\
\hline 11 & French & $\mathrm{F}$ & 52 & Southeast France \\
\hline 12 & French & M & 28 & Paris \\
\hline 13 & French & M & 39 & Southeast France \\
\hline 14 & French & $\mathrm{F}$ & 29 & Southeast France \\
\hline 15 & French & M & 30 & Eastern France \\
\hline 16 & French & M & 17 & Southeast France \\
\hline 17 & French & M & 22 & Southeast France \\
\hline 18 & French & F & 21 & Quebec \\
\hline 19 & French & M & 33 & Paris \\
\hline 20 & French & M & 33 & Paris \\
\hline 21 & French & M & 29 & Eastern France \\
\hline 22 & French & $\mathrm{F}$ & 28 & Southeast France \\
\hline 23 & French & $\mathrm{F}$ & 23 & Southeast France \\
\hline 24 & French & $\mathrm{F}$ & 30 & Northern France \\
\hline 25 & French & $\mathrm{F}$ & 27 & Southeast France \\
\hline 26 & French & $\mathrm{F}$ & 25 & Southeast France \\
\hline 27 & French & M & 25 & Southeast France \\
\hline 28 & French & F & 23 & Southeast France \\
\hline 29 & French & $\mathrm{F}$ & 23 & Southeast France \\
\hline 30 & French & F & 21 & Southeast France \\
\hline
\end{tabular}




\subsection{Stimulus and instructions}

Our data come from oral productions elicited through two different tasks. Prior to the recording the participants were invited to read the following 200 -word text.

Karen was an assistant editor for a small publishing firm. She had a rare hereditary disease called Karpinson's hemotrysoma, characterized by the lack of an enzyme that normally breaks down certain proteins in the digestive system. Because of this, fermented drinks such as wine and liqueurs can cause a severe allergic reaction in someone with the disease.

Karen had just received a promotion so her boss, Mr. Carlson, took her to an expensive French restaurant to celebrate. Mr. Carlson had been to this restaurant several times, so he ordered for both of them. As he looked over the menu, Mr. Carlson considered what to order for Karen. He first thought about ordering the Coquilles Saint-Jacques, but at the last moment decided on the Moules Marinières instead. Although Mr. Carlson did not know this, the Moules Marinières was made in a wine sauce whereas the Coquilles Saint-Jacques did not contain any wine.

Karen enjoyed her meal greatly, but began to feel ill shortly after finishing. Within minutes, she went into convulsions and was rushed away in an ambulance. She died on the way to the hospital.

The original text is in English (Wells \& Gavanski 1986). It was translated into French and Italian and then edited by two native reviewers in each language (see Appendix 1). After reading the text, participants were asked to answer orally the instructions listed in Table 3. Responses were transcribed using the CLAN editor for Childes. Statistical results were obtained using R from Excel files input data.

Table 3. Instructions for the guided interview

\begin{tabular}{lll}
\hline Instructions & Tasks \\
\hline $1 \quad$ & $\begin{array}{l}\text { Proposez trois modifications qui auraient pu empêcher la mort de Karen et } \\
\text { expliquez pourquoi elles l'auraient empêchée. } \\
\text { Imagine three modifications that could have been different in the story to } \\
\text { avoid Karen's death. }\end{array}$ & $\begin{array}{l}\text { Mutation } \\
\text { task }\end{array}$ \\
2 & $\begin{array}{l}\text { Quels effets auraient eu vos modifications sur le rapport entre Karen et } \\
\text { Carlson? }\end{array}$ & $\begin{array}{l}\text { Predictive } \\
\text { task }\end{array}$ \\
& $\begin{array}{l}\text { What would have been the effects of your modifications on the relation- } \\
\text { ship between Karen and Carlson? }\end{array}$ & \\
\hline
\end{tabular}

The use of a decision-making task seemed to us very appropriate to encourage responses from the semantic domain of counterfactuality. The mutation task has been regularly used in the past by a branch of psychological studies interested in the simulation heuristic (Kahneman \& Tvesky 1982; Kahneman \& Miller 1986; Wells \& Gavanski 1989; Miller \& Gunasegaram 1990; Mandel \& Lehman 1996). 
The predictive task was added to our methodology to encourage the production of if-clauses or some kind of hypothetical reasoning marked by conditional forms. In order to complete the predictive task, the learner has to return to the three modifications made in the mutation task and develop them. This places the learner in a continuation task where (s)he can still make use of the lexical repertoire of the stimulus. The analyses applied to the mutation task are quantitative, whereas those for the predictive task are qualitative, but are complemented by some further quantitative results. The quantitative analyses revealed an unbalanced use of some indicative tenses other than the conditional compared to each of the other grammatical devices observed. We therefore provide a qualitative analysis to elucidate the origins of such a preference which may be masked in a purely quantitative analysis.

\subsection{Identifying the mutation cores}

Our mutation task was designed to obtain three responses per participant. The core information of those responses was identified by applying the textual analysis of the Quaestio model (Klein \& von Stutterheim 2006). These authors consider that a given discourse responds to an implicit or explicit question and is shaped by main and side structures. Main structures are those utterances which immediately answer the underlying question, i.e., those which construct alternatives to the actual world $\left(\mathrm{W}_{0}\right)$. Side structures are those utterances in which the speaker addresses background issues, for example by reflecting on the task, giving additional comments, etc. Consider the next example:

(11) 1. *SBJ: et une troisième modification encore oui dans le and a third modification always yes from the

2. ${ }^{\star}$ SBJ: toujours du point de vue de Karen from Karen's point of view

3. *SBJ: c'est que si c'est une affection it's that if it is a disease

4. ${ }^{\star S B J}$ : qui est potentiellement mortelle being potentially fatal

5. *SBJ: elle doit avoir une vigilance de chaque instant she must be aware at all times

6. ${ }^{\star} \mathrm{SBJ}$ : pour tout ce qu'elle ingère concerning everything she eats

7. ${ }^{\star}$ SBJ: et admettons qu'elle ne connaisse pas les moules marinières and just let's pretend she never heard of moules marinières

8. *SBJ: bon quand le serveur lui a amené le plat ok when the waiter brought her dish 
9. *SBJ: aurait dû lui demander she should have asked

10. ${ }^{\star}$ SBJ: est-ce que le plat contenait de l'alcool if the dish contained any alcohol

11. *SBJ: au moins par précaution just as a precaution

In the example above, constructions from the 5th and 9th lines correspond to the text's main structure. Whereas the content of the 5th line belongs to the introduction which the speaker might produce while making up his mind, the content of the 9th line contains the core information that really answers the Quaestio. We will henceforth consider a core mutation as the information segment expressing a different world $\left(\mathrm{W}_{1}\right)$ from the actual world $\left(\mathrm{W}_{0}\right)$. Once we identified the core mutations, we classified them in terms of five grammatical devices. Specifically, we distinguished the responses which included conditional tenses from those which included other indicative forms, subjunctives, if- clauses and nominalizations. Unlike the mutation task, the data elicited in the predictive task were analyzed mainly qualitatively (section 7$)^{9}{ }^{9}$

\section{Quantitative analysis}

Five grammatical devices were elicited from the responses to the mutation task. For the sake of clarity, the responses carrying an indicative verbal form were classified depending on whether they were encoded by a conditional tense (12) or by other tenses semantically expressing factuality (13).

(12) Elle aurait pu choisir toute seule son plat

She could have chosen her own dish

(13) Karen est invitée par son patron [...] mais elle l'avertit qu'elle a une allergie et elle lui demande de choisir elle-même son plat

Karen is invited by her boss [...] but she tells him that she has an allergy and she asks him if she can make her own choice

9. The overuse of indicative tenses other than the conditional in the mutation task was an unexpected result. We therefore decided 'to zoom' in on the productions of those 23 learners with a view to illuminating what lies behind such overuse of indicative tenses other than the conditional. In order to answer this question, we switched to qualitative analyses as opposed to quantitative analyses which may mask the detail underlying use of a wide range of indicative tenses other than the conditional in such contexts. 
Other forms concerned some verbal forms of the subjunctive mood (14), if- clauses (15) and nominalizations (16). For example:

(14) Bah, qu'il commande autre chose que les moules Ahm, he should order something other than the mussels

(15) Si Karen n'avait pas eu de promotion, elle [ne] serait pas morte If Karen had not been promoted, she wouldn't have died

(16) Le fait de ne pas manger des moules marinières The fact of not eating the mussels marinara

\subsection{Learner group}

Overall, as indicated in Table 4, 55 responses were encoded by an indicative tense other than the conditional as in (13) above. This represented $61 \%$ of the 90 responses elicited in the mutation task. A Chi-Squared test showed that the frequency of this grammatical device was significantly higher compared to the if-clauses, $\chi$ $(2, \mathrm{~N}=90)=46.619, p<.001$ and to the conditional tenses, $\chi(2, \mathrm{~N}=90)=31.69$, $p<.001$. As we will see in section 6.2 , this is a major difference compared to the French control group, where indicative tenses other than the conditional are significantly less used than if-clauses and conditional tenses.

The response type of other indicative tenses (13) was produced by 23 of the 30 learners. The seven learners that used other grammatical devices in the mutation task, conditional tenses, if- clauses, subjunctive tenses or nominalizations, were excluded ${ }^{10}$ from the subsequent qualitative analysis of the predictive task. This is because we were interested in discovering what lies behind the learners' overuse of the present tense in contrast with the conditional, and, more precisely, whether this preference concealed some grammatical patterns shared by the 23 learners.

Table 4. Distribution of the grammatical devices in L2 French - Mutation task

\begin{tabular}{|c|c|c|c|c|c|}
\hline Conditional & $\begin{array}{l}\text { Other indica- } \\
\text { tive tenses }\end{array}$ & Subjunctive & If-clauses & Nominalizations & Total $(n=90)$ \\
\hline 17 & 55 & 6 & 10 & 2 & \\
\hline
\end{tabular}

In order to explore whether the overuse of the response type (13) was somehow related to the sociolinguistic characteristics of the learners, we looked at the individual differences between the groups. It could be that these learners had previously had limited instruction in French, but nonetheless had reached a similar level of proficiency. Figure 2 illustrates the amount of instruction in French as a Foreign

10. Subjects $1,4,7,12,25,26,27$.

(C) 2017. John Benjamins Publishing Company

All rights reserved 
Language (FFL) and the duration of immersion in France for the 23 learners who produced the response type (13) in the mutation task. As we indicated previously, in the case of the learners recorded in Nijmegen, their duration of immersion concerns prior visits to France. Three pairs of learners, $6 \& 10,15 \& 17$, and $24 \& 29$, shared the same values on both sociolinguistic traits. This is why Figure 2 presents 20 graphical points covering 23 individual situations or learners. ${ }^{11}$ This group presents a mean of 1.3 years of immersion and 4 years of FFL studies. However, the standard deviation of the immersion group revealed a greater variation from the average compared to the standard deviation of the FFL studies group (see Table 5).

Table 5. Mean on sociolinguistic variables and standard deviation for the subgroup of 23 learners

\begin{tabular}{lcc}
\hline & Time of FFL studies & Time of immersion \\
\hline Group mean & 48.1 months & 15.7 months \\
& $(4$ years $)$ & $(1.3$ years $)$ \\
Standard deviation & 49.9 & 24.1 \\
\hline
\end{tabular}

This means that the data points regarding the learners' amount of FFL studies are clustered closely around the mean, whereas the immersion values are spread slightly further from the mean. Thus, Figure 2 illustrates a compact group regarding

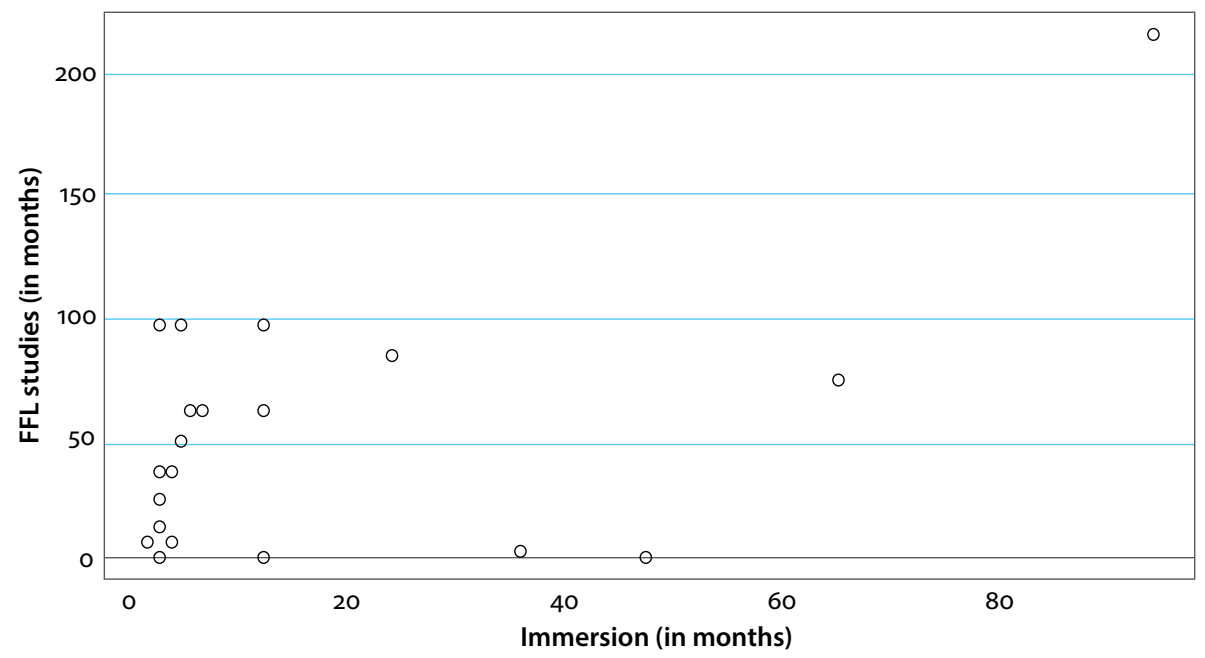

Figure 2. Individual differences across the learners who produced an indicative tense other than the conditional in the mutation task

11. Subjects 15 \& 17 had 12 months of immersion and no prior studies in French as a Foreign Language (FFL); subjects $24 \& 29$ had two months of immersion and 36 months of FFL studies whereas subjects $6 \& 10$ had five months of immersion and 60 months of FFL studies.

(C) 2017. John Benjamins Publishing Company

All rights reserved 
the instructed learning of French and a more eclectic group regarding immersion in the target language. Further analysis linked to each learner production should clarify whether any of these factors accounts for the variable use of the conditional across the 23 subjects. We will address this issue in section 8.2.

\subsection{French L1}

In the control group, 35\% of responses were marked by the combination of the conditional tense and a modal marker as in example (12) above, $21 \%$ by a tense from the subjunctive as in example (14), and $21 \%$ by a conditional construction If $A$ (then) $B$ as in example (15) - see Table 6. No significant differences were found between the frequencies of these grammatical devices, $\chi(3, \mathrm{~N}=90)=7.491$, $p=0.02$. This means that (i) each one of them is used extensively in French and that (ii) they are all similarly distributed in counterfactual contexts. However, the combination of a conditional tense and a modal marker (12) was significantly higher compared to other indicative tenses (13), $\chi(2, \mathrm{~N}=90)=13.265, p<.001$, and to nominalizations $(16),{ }^{12} \chi(2, \mathrm{~N}=90)=18.508, p<.001$. This is a major difference between the control group and the learner group, since for the latter, the present indicative and the imparfait were the most frequently used tenses in the mutation task.

Table 6. Distribution of the grammatical devices in L1 French - Mutation task

\begin{tabular}{cccccc}
\hline Conditional & $\begin{array}{c}\text { Other indica- } \\
\text { tive tenses }\end{array}$ & Subjunctive & If-clauses & Nominalizations & \\
33 & 11 & 19 & 19 & 8 & Total $(n=90)$ \\
\hline
\end{tabular}

\subsection{Italian L1}

In Italian no significant differences were found in the frequencies of the five grammatical devices observed, $\chi(5, N=90)=5.2778, p=0.26$. Unlike French, their distribution in the mutation task was balanced and lacked a dominant, clearly preferred way to mark counterfactuality. Nevertheless, $28 \%$ of responses corresponded to other indicative tenses other than the conditional, followed by if-clauses (20\%), conditional tenses (19\%), verbal forms of the subjunctive mood (19\%) and nominalizations $(14 \%)$ - see Table 7.

12. P-values resulting from the chi-squared test were 0.0004 and $3.731 \mathrm{e}-05$, respectively (Repiso 2013: 73). 
Table 7. Distribution of the grammatical devices in L1 Italian - Mutation task

\begin{tabular}{cccccc}
\hline Conditional & $\begin{array}{c}\text { Other indica- } \\
\text { tive tenses }\end{array}$ & Subjunctive & If-clauses & Nominalizations & \\
17 & 25 & 17 & 18 & 13 & Total $(n=90)$ \\
\hline
\end{tabular}

The statistical results presented here revealed a major difference between the Italian learners and the French control group in their preferred ways to encode counterfactual scenarios in the mutation task. In French L1, no significant differences were found between conditional tenses (12), if- clauses (15) and subjunctive tenses (14), suggesting that they are similarly dominant in the expression of counterfactuality. Conversely, in the learners production indicative tenses other than the conditional (13) were used significantly more often. In order to elucidate the origins of this overuse, the responses obtained in the predictive task were analyzed qualitatively. In the section below, the qualitative results from the predictive task are presented.

\section{Qualitative analysis - Predictive task}

\subsection{French L1}

The native speakers of French responded to the predictive task by means of simple clauses with the past conditional (example 17, 1st to 5th lines) and by if-clauses with the canonical verbal morphology, the plus-que-parfait (pluperfect) in the subordinate clause and the conditional past in the main clause (example 18, 1st and 2nd lines). The plus-que-parfait served to link the counterfactual scenario to a specific point in the common information shared by the speaker and the interviewer. In example (18), this is made by the if-clause of the 1st line (Si les pompiers avaient été plus rapides, If the firemen had been faster), in which the native speaker retrieves a condition mentioned earlier in her discourse production. The combination of foreground information, encoded by conditional tenses, and background information expressed by the plus-que-parfait helps the speaker to construct counterfactual retellings that (i) satisfy the Quaestio and (ii) in which given new information is linked to previously known information. Later we will compare this result with the patterns found in the learner group, and we will observe that the learners who predominantly used the conditional (pattern C) behave like French native speakers in terms of the information levels of their retellings.

(17) 1. ${ }^{\star} \mathrm{SBJ}$ : bah tout se serait bien passé.

Ahm, everything would have been ok. 
2. *SBJ: ils auraient mangé ensemble.

They would have eaten together.

3. ${ }^{\star S B J}$ : et donc voilà tout se serait bien passé.

And therefore everything would have been ok.

4. ${ }^{\star} \mathrm{SBJ}$ : elle [ne] serait pas morte.

She would not have died.

5. *SBJ: et elle aurait fait une brillante carrière.

And she would have had a brilliant career.

[SBJ4]

(18) 1. *SBJ: alors si les pompiers avaient été plus rapides.

So if the firemen had been faster.

2. ${ }^{\star} \mathrm{SBJ}$ : je pense que ça [n'] aurait pas trop changé les rapports.

I don't think that would have changed the relationship that much.

3. *SBJ: que ils auraient eu.

They would have had.

4. ${ }^{\star} \mathrm{SBJ}$ : si ce n'est que beh monsieur Carlson aurait moins culpabilisé.

Unless that ahm Mr. Carlson would not have felt as guilty.

5. *SBJ: étant donné que Karen ne serait pas morte.

Because Karen would not have died.

[SBJ22]

\subsection{Learner group}

Because the conditional in French is said to mark the posteriority of a process whose realization is deferred to certain hypothetical conditions (Charaudeau 1992), it was typically the morphological form that we expected to elicit in the predictive task. However, ten learners did not produce any conditional form at all (subjects $6,9,10,14,15,17,18,24,28,29)^{13}$ and the use of the conditional was asymmetrical for the rest of the learners observed. For a small group of speakers, the conditional was dominant in their responses (subjects $3,11,16,23,30$ ), whereas a larger group rarely used it compared to other indicative tenses $(2,5,8$, $13,19,20,21,22)$. Our qualitative analysis revealed three distinctive patterns in the grammatical devices used to encode counterfactuality.

\subsubsection{Present tense}

A subgroup of eight learners responded only by means of the present tense (subjects $6,9,10,14,15,17,18,24)$. From this subgroup of learners, we identified 99 verbal forms of the present tense. We observed two syntactic patterns in which the speakers structured their discourse: by coordinated clauses linked by copulative and adversative conjunctions as in (19), and by if-clauses which allowed the

13. Subjects $28 \& 29$ produced four and three forms of the imparfait, respectively.

(C) 2017. John Benjamins Publishing Company

All rights reserved 
speaker to frame his/her discourse in relation to a specific situation or context as in (20). For instance:

(19) 1. *SBJ: alors peut-être qu'il passe une bonne soirée. So maybe he is having a good evening.

2. ${ }^{*} \mathrm{SBJ}$ : mais alors monsieur Carlson veut la ramener à la maison. But then Mr. Carlson wants to give her a lift.

3. *SBJ: et ils discutent sur la promotion de Karen. And they discuss on Karen's promotion.

4. ${ }^{\star} \mathrm{SBJ}$ : Karen est très heureuse de ça et très contente. Karen is very happy about it and very glad.

5. *SBJ: et remercie beaucoup son supérieur. And she's very thankful to her boss.

6. ${ }^{\star} \mathrm{SBJ}$ : mais monsieur Carlson à un certain point. But at some point Mr. Carlson.

7. ${ }^{\star} \mathrm{SBJ}$ : peut lui donner l'impression que cette promotion. May give her the impression that her promotion.

8. ${ }^{\star} \mathrm{SBJ}$ : il faut se la gagner.

She has to earn it.

(20) 1. *SBJ: et sinon si le dîner il va continuer bien. And otherwise, if the dinner will continue.

2. *SBJ: elle va manger les coquilles de Saint Jacques. She's going to eat the scallops Saint-Jacques.

3. ${ }^{\star} \mathrm{SBJ}$ : et rien va arriver. And nothing is going to happen.

4. *SBJ: peut-être aussi que elle va tomber amoureuse. Maybe she’s also going to fall in love.

5. ${ }^{\star} \mathrm{SBJ}$ : $d u$ monsieur Carlson on sait jamais. With Mr. Carlson, you never know.

Four learners, subjects 9, 10, 17 and 18, responded to the predictive task using several present tense forms as in example (19). Their responses were marked by the modal adverb peut-être (maybe) and structured in coordinated clauses by means of the conjunctions et (and) and mais (but). Direct speech was used by learners 10 and 17 to retell fictional conversations between the characters of the stimulus (Elle dit mais tu voulais me tuer ou pas? Eh non, il dit, non mais moi j'avais complètement oublié, She says but you wanted to kill me or what? Ah no, he says, but I completely forgot).

Slightly more than one third of the 99 occurrences elicited in the present tense were composed of the periphrastic verb form 'Aller + Infinitive' which is usually used as a periphrastic form to express futurity (lines 2-3-4 of the example above). 
This kind of response is based on the present tense of the verb Aller (go) followed by an infinitive. Overall, seven learners ${ }^{14}$ produced 36 occurrences of this structure in the predictive task: 29 were composed of the $3 \mathrm{rd}$ person singular form $v a+$ infinitive; 4 tokens of the 3rd person plural form vont + infinitive; and 3 tokens of the 1st person singular form vais + infinitive. The semantic role played by the periphrastic future 'Aller + Infinitive' in example (20) is equivalent to the conditional tense. This is because it is used by the speaker to encode the posteriority of a process whose actualization is suspended. In example (20), 'Aller + Infinitive' could be replaced by the conditional tense without modifying the meaning of what has been said (i.e., si le dîner continuait bien, elle mangerait les coquilles [...] et rien n'arriverait, peut-être aussi qu'elle tomberait amoureuse, if the dinner continued, she would eat the scallops [...] and nothing would happen, maybe she would fall in love). The function of 'Aller + Infinitive' is traditionally related to the expression of a proximal future or future progressive. However, the forms elicited in our corpus do not indicate any kind of ulterior actualization but instead are used to express a counterfactual state-of-affairs.

Table 8 reveals that 'Aller + Infinitive' is more prominent than bare present tense forms in the grammars of subject 6 and subject 14. It also suggests that subject 15 and subject 18 use both devices equally, whereas bare present tense forms seem to be preferred by subjects 9,10 and $17 .^{15}$

Table 8. Distribution of the present tense forms and Aller + Inf. across the learners Predictive task

\begin{tabular}{lcrrrrrrrc}
\hline & SBJ6 & SBJ9 & SBJ10 & SBJ14 & SBJ15 & SBJ17 & SBJ18 & SBJ24 & Total \\
\hline Present & 4 & 15 & 15 & 3 & 3 & 12 & 9 & 2 & 63 \\
Aller + Inf. & 10 & 1 & 3 & 8 & 3 & 5 & 6 & 0 & 36 \\
& 14 & 16 & 18 & 11 & 6 & 17 & 15 & 2 & 99 \\
\hline
\end{tabular}

A further frequent present tense form used is c'est (it is). In L2 French, this form is used by beginner learners as a lexical marker to compensate for the lack of more elaborated markers of time, like inflectional verbal morphology. We decided to look at the production of this form with the intention of collecting additional data on each learner's production. A total of 28 occurrences were elicited in the predictive task from eight different learners from pattern A (subjects 6, 10, 14, 15, 17, 18, 24 and 29). In particular, subjects $6,10,14,15,17$ and 18 produced four occurrences each. For example:

14. Subjects $6,9,10,14,15,17,18$.

15. The brief production of subject 24 in the predictive task - with only two verbal forms elicited - does not allow us to make any general consideration. 
(21) 1. *SBJ: alors la dernière [modification] que j'ai dit c'est pas de promotion. $\mathrm{Ok}$, so the last one that I said it's no promotion.

2. ${ }^{\star S B J}$ : c'est rien qui change.

It's nothing that changes.

3. ${ }^{\star} \mathrm{SBJ}$ : si c'est elle qui reste assistante à l'édition.

If it's her who keeps working as assistant editor.

Note that example (21) can be paraphrased by replacing c'est (it is) by more sophisticated temporal markers. For example: Alors la dernière [modification] que j'ai dit, il n'y aurait pas eu de promotion, il n'y aurait eu rien qui change si c'était elle qui restait assistante à l'édition (Ok, so the last one that I said, it would have had no promotion, no change would have happened if she had kept her position as an assistant editor). Here, we have replaced the c'est of the 1 st and 2 nd lines by two impersonal verbal forms of the past conditional and the c'est of the 3rd line by a form of the indicative imparfait, in line with the canonical verbal morphology of French if-clauses. The use of c'est enables the production of non-conjugated predication and, at the same time, a fluency gain (Bartning 1997). Evidence has been given about the non-native use of c'est (it is) instead of il y a (there is), and about its combination with an adjective or a noun phrase, which often leads to ambiguous referential meanings (Bartning 1997: 35). This author explains the overuse of c'est by her Swedish non-advanced learners as a strategy of avoiding complex verbal inflections. The data on which Bartning (1997) based her results come from guided interviews with university learners who had completed between one to four semesters of FFL studies and had lived in France for between one to 18 months.

\subsubsection{Use of the conditional}

A subgroup of eight learners responded to the predictive task using mainly indicative tenses semantically anchored to factuality, although the conditional tense was occasionally elicited as well (subjects $2,5,8,13,19,20,12,22)$. This subgroup produced 12 forms of the conditional expressing a counterfactual event or stateof-affairs and 52 verbal forms which included 24 occurrences of the present, 25 occurrences of the imparfait, 2 of the passé composé and one of the inflected future. The asymmetrical use of the conditional compared to other indicative tenses creates an imbalance in which the foregrounded information is often expressed both by canonical and non-canonical devices. For example:

(22) 1. *SBJ: alors bon dans le cas où. So, in the case where.

2. *SBJ: au cas où Karen ne. In the case that she doesn't. 
3. ${ }^{\star} \mathrm{SBJ}$ : refuse le rendez-vous.

She refuses to meet him.

4. ${ }^{\star} \mathrm{SBJ}$ : parce qu'elle craint recevoir des avances.

Because she fears to be overwhelmed by his advances.

5. ${ }^{\star} \mathrm{SBJ}$ : peut-être monsieur Carlson commence à se comporter.

Maybe Mr. Carlson begins to behave.

6. *SBJ: de façon un peu agressive au boulot.

A bit aggressively at work.

7. *SBJ: à lui faire du mobbing [...].

And she's bullied by him.

8. *SBJ: au cas où le monsieur Carlson choisit un plat différent.

In the case that Mr. Carlson orders a different dish.

9. *SBJ: tout simplement il y aurait pas des gros changements je crois.

Simply, it wouldn't have great changes I think.

10. *SBJ: sauf si Karen est vraiment dégoûtée par les coquilles Saint-Jacques. Unless if Karen is really upset because of the scallops Saint-Jacques.

[SBJ21]

The example above contains two counterfactual scenarios, one in which Mr. Carlson would begin to behave aggressively (5th line) and another in which no noticeable effects would happen (9th line). However, the former is expressed by the present tense and the latter by the conditional tense. In the example below, the speaker uses both the conditional tense and the imparfait to assess two different scenarios different from the actual world (5th and 8th lines, respectively).

(23) 1. ${ }^{\star} \mathrm{SBJ}$ : le fait qu’elle avait une rare maladie héréditaire.

The fact that she had a rare hereditary disease.

2. *SBJ: si elle n'avait pas eu une rare maladie héréditaire eh.

If she had not had a rare hereditary disease ahm.

3. * $\mathrm{SBJ}$ : ok si elle n'aurait pas eu sa promotion dans son travail.

$\mathrm{Ok}$, if she would not have had her promotion at work.

4. ${ }^{\star} \mathrm{SBJ}$ : le rapport entre Karen et son supérieur. The relationship between Karen and her boss.

5. *SBJ: peut être serait resté le même qu'avant la promotion.

Maybe would have remained as it was before the promotion.

6. *SBJ: la deuxième [conséquence] c'est que.

The second [effect] is that.

7. *SBJ: si elle n'avait pas la rare maladie héréditaire.

If she didn't have the rare hereditary disease.

8. ${ }^{\star} \mathrm{SBJ}$ : le rapport c'était le même.

The relationship was the same.

[SBJ8]

(C) 2017. John Benjamins Publishing Company

All rights reserved 
In the example above, the verbal morphology of the if-clauses elicited does not seem to be stable. In the second line, the speaker produces the plus-que-parfait (pluperfect) in the subordinate clause, which is the canonical tense in French. In the third line, however, the learner seems to correct herself when she uses the conditional tense. Table 9 summarizes the differences between the occurrences of the conditional tense and the other indicative tenses observed. Within the latter, the present indicative clearly dominates in the productions of subjects 2, 20 and 21 , whereas the imparfait characterizes the responses of subjects 5, 8 and 19 . These two preferences have been highlighted supra in examples (22) and (23). The short production of subject 22 differs from the rest of the subgroup and thus, does not provide a clear picture of the learner's verbal system.

Table 9. Distribution of the conditional tense across the learners - Predictive task

\begin{tabular}{lccccccccc}
\hline & SBJ2 & SBJ5 & SBJ8 & SBJ13 & SBJ19 & SBJ20 & SBJ21 & SBJ22 & Total \\
\hline Conditional & 1 & 2 & 2 & 2 & 1 & 2 & 1 & 1 & 12 \\
Other forms & 8 & 7 & 10 & 4 & 6 & 9 & 7 & 1 & 52 \\
& 9 & 9 & 12 & 6 & 7 & 11 & 8 & 2 & 64 \\
\hline
\end{tabular}

\subsubsection{More frequent use of the conditional}

In contrast to these learners who use the conditional minimally, a subgroup of five learners responded to the predictive task using mainly the conditional tense (subjects 3,11, 16, 23, 30). This subgroup produced 34 forms of the conditional expressing a counterfactual event or state-of-affairs. Unlike the subgroup presented in section 7.2.2, the learners producing conditional tenses in the prediction task showed a repertoire of if- clauses coherent with the canonical description of the verbal morphology (i.e., the plus-que-parfait in the subordinate clause and the past conditional in the main clause), as exemplified in the following learners' productions.

(24) 1. *SBJ: elle serait pas morte.

She would not be dead.

2. ${ }^{\star}$ SBJ: Carlson aurait pu avoir son employée le lendemain.

Carlson might have had his employee the day after.

3. ${ }^{\star} \mathrm{SBJ}$ : elle aurait savouré le repas.

She would have enjoyed the meal.

(25) 1. *SBJ: alors si Karen avait décidée de ne pas manger.

So if Karen had decided not to eat.

2. ${ }^{\star} \mathrm{SBJ}$ : les moules que son chef avait commandées pour elle.

The mussels that her boss had ordered for her. 
3. *SBJ: il y aurait eu une situation un quelque peu embarrassant. There would have been a bit of an embarrassing situation.

4. ${ }^{\star} \mathrm{SBJ}$ : entre son- le chef et Karen.

Between her- the boss and Karen.

5. ${ }^{\star} \mathrm{SBJ}$ : parce qu'il aurait pu considérer cela comme un manque de respect. Because he might have considered this like a lack of respect.

[SBJ3]

While example (24) directly answers the Quaestio of the predictive task, example (25) contains two information levels. The subordinate clause introduced by the conjunction if-is used to situate the counterfactual scenario within a particular set of conditions different from $\mathrm{W}_{0}$ (1st and 2nd lines) and thus, it can be considered as background information. In contrast, we consider the content of the 3rd and 5 th lines as foreground information. Firstly, the hypothesis of an embarrassing situation between Karen and Carlson adds new information to the background shared by the speaker and the interviewer. Secondly, the lines mentioned are the only segments that properly satisfy the interviewer's request (i.e., the possible effects of Karen's survival). Table 10 presents the differences between the conditional tense, on the one hand, and the imparfait and the plus-que-parfait, on the other hand, for each of the five learners.

Table 10. Distribution of the conditional tense across the learners - Predictive task

\begin{tabular}{lcccccc}
\hline & SBJ3 & SBJ11 & SBJ16 & SBJ23 & SBJ30 & Total \\
\hline Conditional & 12 & 6 & 3 & 7 & 6 & 34 \\
Imparfait or $P Q P$ & 2 & 1 & 0 & 2 & 3 & 8 \\
& 14 & 7 & 3 & 9 & 9 & 42 \\
\hline
\end{tabular}

Note that the frequencies of conditional forms are higher than the sum of those of the imparfait and the plus-que-parfait in each of the learner productions. This allows the speaker to construct counterfactual retellings in which foreground information - encoded by conditional tenses - is dominant, and which may be supported by comments and background information expressed by the imparfait and the plus-que-parfait. As shown in example (23), the imparfait and the plus-queparfait were used to relate the counterfactual scenario to a specific point in the background information shared by speaker and interviewer.

\subsection{Summary of the learners' patterns}

So far, our analyses have revealed three distinctive patterns behind the overuse of the present tense and the imparfait in counterfactual contexts. The absence of any form of the conditional tense was a common feature for ten learners (subjects 6, 9, 
$10,14,15,17,18,24,28,29)$. The rest of the learners produced at least one or more forms of the conditional. However, the use of the conditional tense was asymmetrical, being infrequent in the grammars of eight learners $(2,5,8,13,19,20$, 21,22 ) and dominant in the grammars of five learners (subjects $3,11,16,23,30$ ).

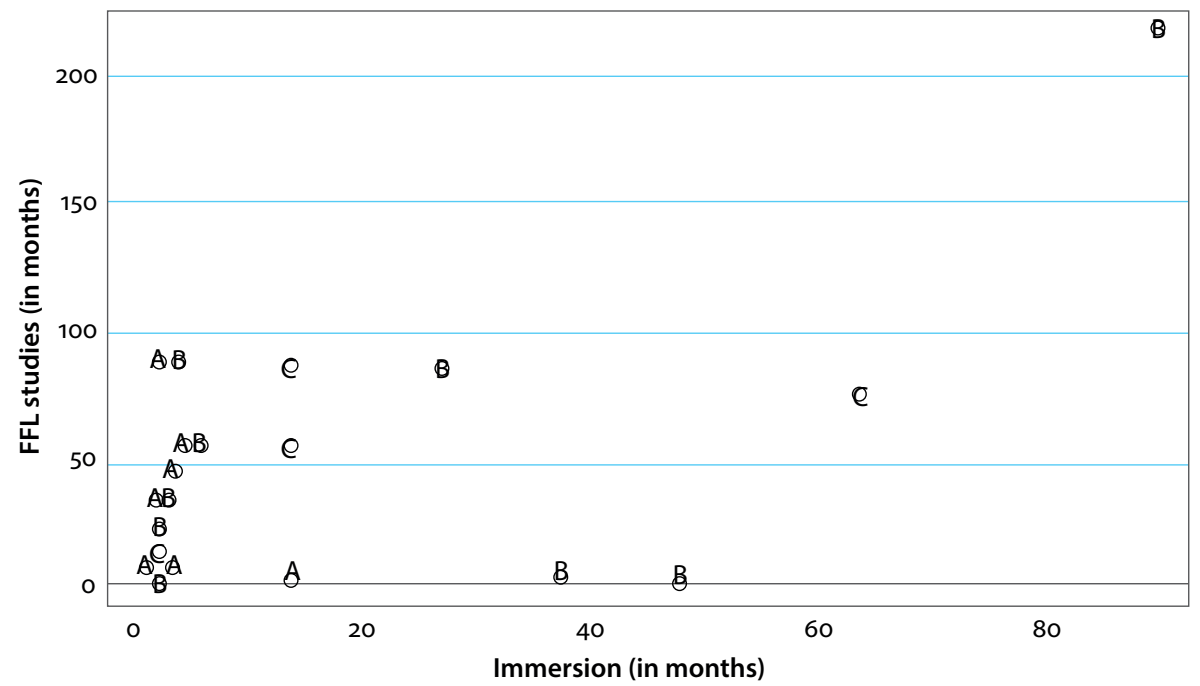

Figure 3. Verbal repertoire of the learners in the predictive task

Figure 3 illustrates the three distinctive patterns explained in section 7.2 in relation to the sociolinguistic traits of each of the 23 learners: immersion and instruction in French. We use the letter A to distinguish the group of learners who did not use any form of the conditional from the group of learners who used the conditional tense poorly (B) and the group who used it frequently (C). Figure 3 illustrates 20 graphical points that cover 23 speech productions in the predictive task. This is because three pairs of learners shared the same values on both the duration of immersion and the amount of FFL studies (pairs $6 \& 10,15 \& 17$, and $24 \& 29$ ). The grammars of these six learners lacked any form of the conditional tense (pattern A). At first sight, Figure 3 reveals a left-down area covering the productions of all speakers from pattern A. The maximum values of this subgroup are 100 months of FFL studies ( 8.3 years) and 20 months of immersion (1.6 years). We will discuss the impact of these variables in the use of the conditional tense in section 8 .

Figures 4 to 6 show how the duration of FFL studies and immersion affect the type of response produced in the predictive task. The decreasing line in Figure 4 predicts that the features described in pattern A are likely to be abandoned by learners beyond a certain time. Conversely, the increasing lines in Figure 5 and 6 predict that the features described in patterns $\mathrm{B}$ and $\mathrm{C}$ are more likely to be used by those learners presenting higher levels of FFL studies and immersion. 


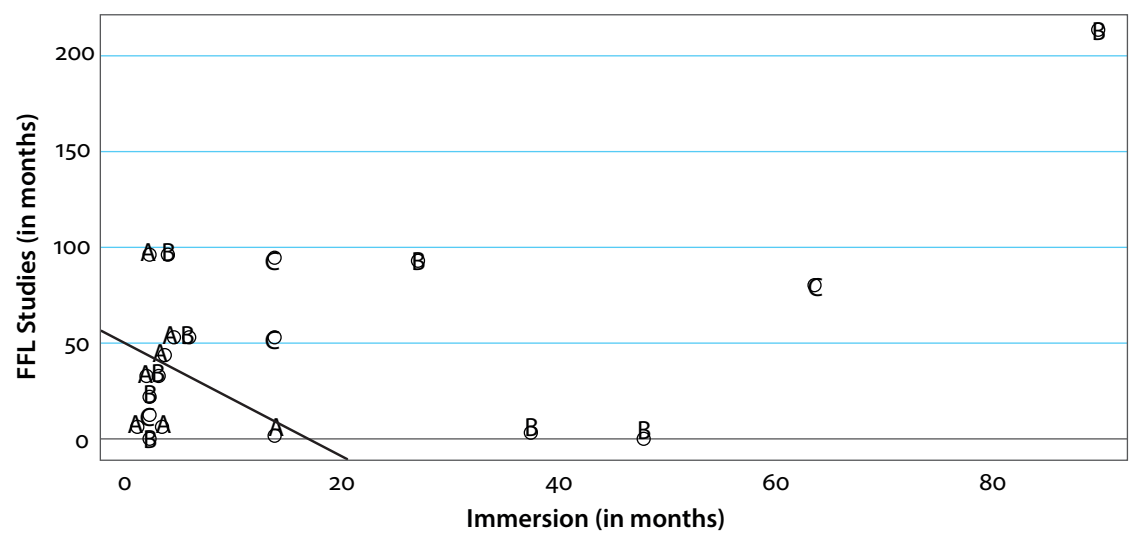

Figure 4. Linear regression calculated on the sociolinguistic variables of learners demonstrating pattern A

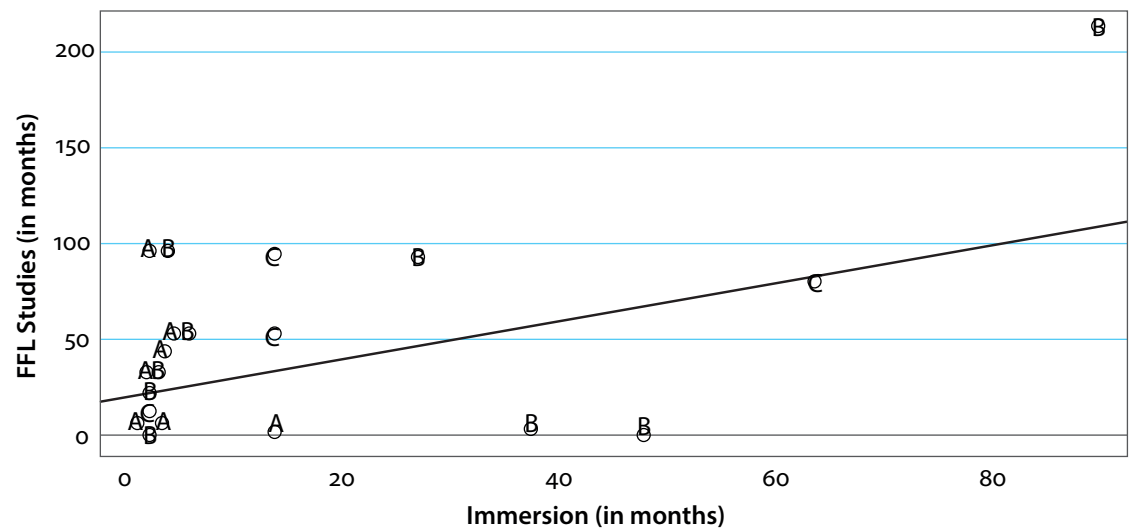

Figure 5. Linear regression calculated on the sociolinguistic variables of learners demonstrating pattern $B$

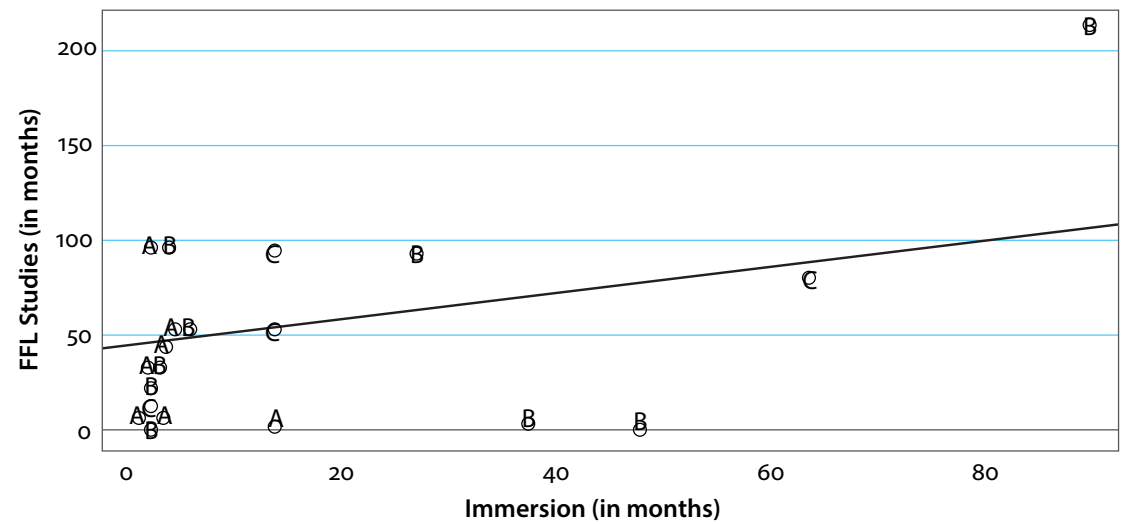

Figure 6. Linear regression calculated on the sociolinguistic variables of learners demonstrating pattern $\mathrm{C}$

(C) 2017. John Benjamins Publishing Company

All rights reserved 
Tables 11-13 summarize the mean of FFL studies and immersion per subgroup. The learners whose production has been classified as pattern A are a compact group with regard to the immersion variable, presenting an average of 4.8 months. In contrast, the subgroups $\mathrm{B}$ and $\mathrm{C}$ have a greater variability although both of them present an immersion average that goes beyond one year. As for the time of FFL studies, again subgroup $\mathrm{A}$ is a more compact set than subgroups B and C. The former has an average of 2.9 years, whereas the latter present an average higher than 4 years.

Table 11. Pattern A: Mean on sociolinguistic variables (in months) and standard deviation

\begin{tabular}{lcc}
\hline & Time of FFL studies & Time of immersion \\
\hline Group mean & 34.8 & 4.8 \\
Standard deviation & $(2.9$ years $)$ & $(0.4$ years $)$ \\
\hline
\end{tabular}

Table 12. Pattern B: Mean on sociolinguistic variables (in months) and standard deviation

\begin{tabular}{lcc}
\hline & Time of FFL studies & Time of immersion \\
\hline Group mean & 60.2 & 27.2 \\
Standard deviation & $(5$ years $)$ & $(2.3$ years $)$ \\
\hline
\end{tabular}

Table 13. Pattern C: Mean on sociolinguistic variables (in months) and standard deviation

\begin{tabular}{lcc}
\hline & Time of FFL studies & Time of immersion \\
\hline Group mean & 55.2 & 19 \\
Standard deviation & $(4.6$ years $)$ & $(1.6$ years $)$ \\
\hline
\end{tabular}

\subsection{Italian L1}

Unlike the L1 French group, the data found in L1 Italian highlight two main ways of responding to the predictive task. On the one hand, we identified a general pattern characterized by the combination of some verbal forms of the subjunctive and the conditional (speakers 2, 3, 5, 8, 11, 14, 16, 18, 20, 21, 22, 23, 28, 30). On the other hand, we identified a less extensive pattern characterized by a larger variety of indicative tenses containing a counterfactual narration marked frequently by the present tense (learners $6,9,10,13,15)$. In the examples below, (26) is representative of the canonical pattern, whereas (27) and (28) are representative of counterfactual narrations marked by the present tense. 
(26) 1. *SBJ: la terza [modifica] se Karen non fosse stata promossa. The third [modification], if Karen had not been promoted.

2. ${ }^{*} \mathrm{SBJ}$ : diciamo che Karen sarebbe stata meno contenta.

Let's say that Karen wouldn't have been as glad.

3. ${ }^{*} \mathrm{SBJ}$ : e comunque non sarebbe uscita a cena con il signore.

However she wouldn't have gone out to dinner with him.

4. ${ }^{\star} \mathrm{SBJ}$ : e quindi non si sarebbero probabilmente conosciuti meglio.

And thus they wouldn't have known each other better.

5. ${ }^{\star}$ SBJ: come può succedere durante una cena.

As it might happen during a dinner.

(27) 1. *SBJ: e quindi immagino che a quel punto succeda qualche cosa.

And thus, at that point, I can imagine that something happened.

2. ${ }^{\star} \mathrm{SBJ}$ : per cui Karen o decide di stare al gioco.

And either Karen decides to play along with Mr. Carlson.

3. ${ }^{\star} \mathrm{SBJ}$ : e diventare la amante di questo capo.

And to become his mistress.

4. ${ }^{*} \mathrm{SBJ}$ : o decide di tenere fermi i suoi principi la sua dignità.

Either she decides to stick to her own principles and dignity.

5. *SBJ: e denuncia il suo avventore e cambia lavoro.

And she pleas against her aggressor and leaves her job.

6. ${ }^{\star} \mathrm{SBJ}$ : e magari anzi forse magari tiene la promozione.

And maybe, furthermore, maybe she gets her promotion.

7. *SBJ: perché monsieur Carlson.

Because Mr. Carlson.

8. ${ }^{\star} \mathrm{SBJ}$ : il signor Carlson viene giudicato colpevole dalla polizia.

Mr. Carlson pleaded guilty to the police.

9. ${ }^{\star} \mathrm{SBJ}$ : e viene incarcerato magari o perde il posto.

And he is sent to prison or loses his job.

(28) 1. *SBJ: la seconda [modifica] ho detto che lui era a conoscenza.

The second [modification] I've said that he was aware [of Karen's illness].

2. ${ }^{*}$ SBJ: discutono della sua malattia.

They discuss her illness.

3. *SBJ: quindi magari sai si crea un legame più stretto.

So that maybe, you know, it creates a more intimate bond.

4. ${ }^{\star} \mathrm{SBJ}$ : fra lei e il suo capo proprio perché possono.

Between her and her boss because they can.

5. *SBJ: discutono della malattia.

They discuss the illness.

6. ${ }^{\star} \mathrm{SBJ}$ : e di insomma di come vive lei questo stato.

And about how she lives with it. 
Example (27) corresponds to the final fragment of the response to the predictive task. It was preceded by an initial fragment in line with the canonical way in which counterfactuality is generally marked in Italian (i.e., the subjunctive usually introduces a condition different from the actual world, whereas the conditional is used to develop the consequence of the non-actualized condition). Speaker 9 switched spontaneously from the canonical pattern to a succession of coordinated clauses carrying the present tense. The counterfactual narration of example (27) is structured mainly by the copulative conjunction $e$ (and), constituting five occurrences and parallel counterfactual scenarios are proposed after the conjunction $o$ (or). The counterfactual interpretation of the present tense is reinforced by the use of hypothetical markers like forse and magari (maybe) (four occurrences). Note that the counterfactual narration from the 2 nd to the 9 th lines occurs immediately after the speaker explicitly alerts the hearer to the fictional nature of what is being proposed (i.e., e quindi immagino che a quel punto succeda qualcosa; and thus, at that point, I can imagine that something happened). Example (27) shares some of the characteristics of example (28) but we quote it above because of the colloquial element sai (you know, 3rd line). The speaker is constructing a counterfactual scenario anchored in the present tense when she suddenly produces an overt colloquial morpheme by which she validates the plausibility of her counterfactual scenario.

We found some variability within the less canonical pattern represented above by examples (27) and (28). Some speakers used the present tense to accomplish the predictive task from beginning to end (speakers 6 and 10), other speakers switched to the present tense (subject 9) and the imperfetto (subject 13) from a combination of forms from the subjunctive and the conditional, and another speaker switched instead to the canonical pattern of the present tense (subject 15).

In sum, we have shown that native French speakers and native Italian speakers responded differently to the predictive task. The Italian group used either the present indicative or the past conditional, whereas the French group particularly used the past conditional. Within the learner group, we identified three strategies to encode irreality in L2 French: eight learners marked counterfactuality by means of bare present tense forms and the periphrastic future 'Aller (to go) + Infinitive' (pattern A), eight learners produced some rare forms of the conditional combined with other indicative tenses (pattern B), and five learners produced the past conditional prominently (pattern C). 


\section{Discussion}

In this section, we will consider our results in relation to previous studies with a view to answering the research questions presented in section 4 . First, we will discuss to what extent the present indicative and the conditional are reliable clues to the learners' proficiency. Second, we will examine the role of immersion in the use of the first conditional forms. Third, we will discuss the learners' preference to use the present indicative in non-factual contexts, and finally we will highlight the role of the present indicative and the imperfetto in Italian as potential sources of L1 transfer.

\subsection{Verbal morphology and L2 proficiency}

Our data suggest that the dominant use of the present indicative to mark counterfactuality is not necessarily reflective of a basic level of general L2 proficiency. Rather, the high frequency of this tense in the mutation task takes the form of different markers pointing to different origins underlying use of such non-canonical forms across the 23 heterogeneous learners observed. Indeed, our qualitative analysis showed that some of these learners did not produce any other tenses, even though the interviewer's input included several past conditional forms. The learners could therefore have aligned their verbal repertoires to the input and switched from the present indicative to a variable use of the conditional.

In Section 7.2, we have shown how four learners from pattern A talked about what might have been using bare present tense forms in French. ${ }^{16}$ These four learners produced $80 \%$ of the present tense forms elicited in the predictive task from pattern A. Their counterfactual scenarios were marked by the modal adverb peutêtre (maybe) and structured around coordinated clauses by means of the conjunctions et (and) and mais (but). The periphrastic future 'Aller + Infinitive' was also frequently observed in the learners grouped under pattern $A$ to encode the posteriority of a process whose realization is suspended. This result is similar to Bernini's (1994) description concerning the dominant use of the future tense to mark hypothetical scenarios in the acquisition of Italian by beginner, non-guided learners. The data analyzed by this author show that the periphrastic future is relatively more used than the present tense to mark hypothetical states-of-affairs. We can therefore consider the prominent use of 'Aller + Infinitive' in the productions of learners 6 and 14 as a confirmation of Bernini's results. In the case of basic learner

16. Subjects 9 and 10 produced 15 occurrences each, subject 17 produced 12 , and subject 18 produced 9 (cf. Table 8 ). They produced 51 out of the overall 63 present tense forms elicited in the predictive task from pattern $\mathrm{A}$. 
varieties, the counterfactual interpretation of forms of the present is made possible because of the discursive context (Bernini 1994). Under these conditions, we might consider the recurrent use of 'Aller + Infinitive' as a resource in the learner's grammar that will be progressively replaced by the canonical conditional tense.

Apart from the latter form, we have also noted the learners' frequent use of c'est. The use of this form has previously been described as a characteristic feature of the production of less advanced learners (Bartning 1997) and appears to be processed as a lexical item (Bartning \& Schlyter 2004). Studies of non-guided learners have shown that, at the very early stage of L2 acquisition, temporal marking is realized by means of lexical items rather than inflectional morphology (Klein $\&$ Perdue 1997). In the predictive task, we elicited 28 occurrences of c'est from eight learners demonstrating pattern A. In particular, six of them produced four occurrences each (cf. section 7.2.1). Such levels of frequency contrasted with the general use of c'est by the rest of the learners observed, from whom we elicited a maximum of two occurrences (subjects 20 and 23), one occurrence (subjects 5, $8,11,13$ and 30 ) or none at all (subjects 2, 3, 16, 21 and 22). ${ }^{17}$ In section 5.1, six learners were labelled as potentially non-advanced due to their low values on immersion time and guided instruction. Our qualitative analysis has shown that at least four of them (subjects 14, 15, 17 and 18) shared the following characteristics: the non-production of conditional forms, the overuse of the present indicative or the periphrastic Aller + infinitive and the overuse of c'est as a lexical item (4 occurrences each). These regularities suggest that the grammars of these learners are less developed than the rest of their counterparts.

A factor frequently mentioned as pointing to the more advanced proficiency of learners is based on tense agreement, and more specifically on the production of the plus-que-parfait alongside the past conditional within if-clauses. Use of these tenses has been described as a feature characterizing an intermediate level within the advanced stage (Bartning \& Schlyter 2004). Variation with regard to these forms within some if-clauses was found in the production of subjects displaying pattern $B(8,20,21$ and 22) and C (11 and 23). Only three learners from pattern C (subjects 3, 16 and 30) produced the plus-que-parfait and the past conditional regularly within their if- clauses, ${ }^{18}$ like the control group. Learner 5 from pattern $\mathrm{B}$ also produced some if-clauses in line with the French canonical system outside the two tasks analyzed in the present article. The variation found within patterns B

17. The only exception to the low frequencies of c'est was found in the production of subject 19, from whom we elicited five occurrences. This amount is similar to those found in the learners classified within pattern A. Subject 19 produced one single conditional form in the predictive task, five forms of the imparfait and one of the present tense.

18. Data elicited in other tasks different from the predictive task (for details, cf. Repiso 2013). 
and $\mathrm{C}$ with regard to the learners' use of such grammatical resources suggests that beyond a minimal period of immersion or FFL studies, which seems necessary for the learner to integrate conditional forms in their system, the use of the present in counterfactual contexts continues to occur, and it is not necessarily indicative of a low level of proficiency. In other words, some learners use the present indicative in counterfactual readings, while also using complex aspects of the L2 verbal system, as in the case of if-clauses or the subjunctive following certain modal markers (Il faut qu'elle fasse toujours gaffe à tout ce qu'elle mange she has to be always careful with everything she eats). Further studies are still necessary in order to obtain a complete overview of the acquisitional trajectory followed by the learner to mark time in counterfactual contexts. The application of more finely tuned methods to distinguish a priori well delimited levels of L2 proficiency would help us to better understand how intermediate learners and advanced learners proceed.

\subsection{The role of immersion in the production of conditional forms}

Following the grouping of the 23 learners in three distinctive patterns, statistical analyses revealed a significant difference between groups A and B concerning the immersion variable. This means that immersion can be taken as a reliable explicative factor underlying the speakers' different patterning for those learners who rarely used the conditional (pattern $\mathrm{B}$ ) and those who produced no conditional forms at all (pattern A). Conversely, no significant differences were found between the learners' patterns with respect to the duration of instruction. The learners who expressed counterfactual scenarios by means of the present tense (pattern A) had lived in France for a time span of between one and twelve months. Apart from subjects 15 and $17,{ }^{19}$ the rest of the speakers from pattern $A$ had an immersion period equal to or less than five months. In light of such results, having lived in France for more than one year seems to have benefitted the production of conditional forms in counterfactual contexts. The lack of significant differences across the patterns depending on the learners' instruction leads us to consider this variable as less influential than immersion. This result supports the conclusion of Howard (2012) concerning the advantageous role of immersion over guided instruction for English learners of French.

19. The lack of conditional forms in the case of subjects 15 and 17 who had one year of immersion can be explained because of their particular situations. Subject 15 was recorded after a year during which she had worked as a teacher's assistant of Italian. She lived in France with her Italian partner; the dominant language in their daily life was Italian. Subject 17 was recorded in Nijmegen but worked in Germany. She had lived in France for one academic year during her $\mathrm{PhD}$, four years prior to our data collection. 


\subsection{Stylistic preference}

The coexistence in the learners' system of a canonical way to encode irreality, by means of the conditional tense, and a non-standard way, by means of the present tense, might be explained by a stylistic preference in which the latter can be considered as a colloquial license to frame narrative texts. Previous studies have shown that the present tense is spontaneously selected by native speakers when they are asked to tell "what happened" in an oral narrative (Carroll et al. 2008; Dimroth et al. 2010) or when they frame their production in fictitious discourse (Klein 2009; Krifka 2012). Our study also shows the dominant use of the present tense to encode counterfactuality in L2 French by 23 heterogeneous learners (i.e., those classified within pattern $\mathrm{A}$, who have not integrated the conditional tense in their language system versus those classified within patterns $B$ and $C$, in which the use of the conditional varies from infrequent to dominant). The overuse of the present tense in the former case has been explained by their basic learner variety with regard to verbal morphology and the recurrent use of c'est as a lexical item (cf. section 8.1). However, the overuse of the present tense is more difficult to explain for the rest of the learners observed. The learners in groups B and C seem to have integrated the conditional tense into their grammars because each of them produced several occurrences of it during the task. We cannot exclude the idea that they use the present as a stylistic license, like native speakers do when asked to retell past events (Carroll et al. 2008, Dimroth et al. 2010) or fictional stories (Kifka 2012). Interestingly, the learners in groups B and C behaved differently compared to the input provided in the task which contained a large number of past conditional forms. Only a small group of learners (pattern C) switched from the present tense to a more dominant use of past conditional forms. This means that stylistic preferences can be abandoned at one point of the interaction with the aim of adjusting the L2 production to the interlocutor's behavior.

\subsection{L1 influence}

Even if the grammatical devices elicited in the mutation task in Italian were similarly distributed and no significant differences were found among their frequencies, the most frequent grammatical device in absolute terms was indicative tenses and not the conditional, $28 \%$ in relative terms (cf. section 6.3). This is the main reason why $\mathrm{L} 1$ influence cannot be discarded as an explicative factor. The heterogeneous devices shown in example (9) by Bernini's native Italian speaker recall 
those in examples (27) and (28). ${ }^{20}$ In section 7.4 we described how four native Italian speakers produced counterfactual scenarios through a succession of coordinated clauses carrying only verbal forms in the present tense (subjects 6 and 10) or in combination with some forms of the subjunctive (subjects 9 and 15). The present tense is sometimes used in Italian to express counterfactual scenarios generally structured around coordinate clauses, giving rise to linear or chronological narrations.

In this study, the imperfetto (i.e., the equivalent of the French imparfait) was frequently used in L1 Italian in the predictive task by one native speaker, subject 13 , in combination with some forms of the subjunctive and the conditional (cf. section 7.4). In spoken Italian, the imperfetto is frequently used instead of the conditional tense in colloquial contexts (e.g., Se venivi, lo vedevi, If you had come, you would have seen it, Renzi \& Salvi 1991). This L1 preference seems to interfere in the L2 production. In L2 French, symmetrical uses of the present indicative and the imperfetto marked 41 if-clauses produced by Italian learners (Il [ne] donne pas une promotion si après il veut la tuer, He does not give a promotion if he's willing to kill her; Si elle disait à son patron qu'elle voulait choisir elle-même son assiette, c'était aussi une manière de s'imposer, If she told her boss that she wanted to choose for herself, it was also a way to empower herself). ${ }^{21}$ From this point of view, the use of the imparfait in L2 French in counterfactual scenarios may be related to the native pattern in Italian of ascribing the imperfetto to narrative contexts, covering either factual states-of-affairs in the past or non-actualized states-of-affairs. The former use is usually described as temporal and the latter as modal (Barceló \& Bres 2006). If native speakers use the imperfetto in Italian as a way of framing narrative texts in general, and counterfactual narrations in particular (Renzi \& Salvi 1991), then it is possible that in their L2, they reproduce this behaviour by means of the French imparfait.

20. The integration of the imperfetto in the grammars of non-instructed learners belonging to the basic variety has been explained in L2 Italian as quotation strategy (Bernini 1994). This author claims that the learners first associate the imperfetto with reported speech in the L1 input. This association would trigger a mnemonic process by which learners integrate the imperfetto in their grammar as a 'routine' form. In other words, when the learner starts to use the imperfetto, (s)he is not aware of its modal value, although (s)he can produce it in hypothetical contexts (personal communication).

21. For additional data, cf. Repiso (2013: 139).

(C) 2017. John Benjamins Publishing Company

All rights reserved 


\section{Conclusion}

We have explored the use of the present indicative to encode counterfactuality in L2 French by a heterogeneous group of Italian learners. Our results suggest that the use of this form is particularly characteristic of the learners who have been immersed in the target language environment for a period of less than six months. Moreover, the overuse of the present tense seems to be a mechanism to compensate for the absence of the conditional form in the learner's interlanguage. In contrast, the use of the present indicative in counterfactual contexts is less homogeneous in more experienced learners in terms of immersion and instruction. We have found that the present indicative was frequently used either by learners able to produce past conditional forms and by learners who use it as a non-marked means to express counterfactuality. Our data show that the non-canonical use of the present tense hides a more sophisticated pattern in which the past conditional becomes prominent for a small group of learners. One condition that seems to influence the switching from the present tense to the native use of the past conditional is the recurrent use of the latter in the input provided in the task. However, we found that the present indicative is frequently used even by learners who align their productions to the native pattern. This has been explained as a stylistic preference. Further research is necessary in the domain of counterfactuality in order to test how such stylistic preferences may be attributable to the role of the present indicative and the imperfetto in Italian in terms of an effect for L1 transfer. Our survey highlights the role of qualitative analysis in offering more fine-grained insights than quantitative analysis alone would have permitted. In particular, by applying qualitative methods we have shown that the use of the present tense to encode counterfactuality in French may have different sources. Of course, the grammatical devices to mark time cover other categories that we have not analyzed in the present article, such as temporal adverbials, aspect and discourse principles. Further studies focusing on these categories will be necessary to obtain a more complete picture of the expression of counterfactuality.

\section{Acknowledgments}

I express my gratitude to the anonymous reviewers and to Pascale Leclercq and Martin Howard for their precious remarks. Many thanks to my fellow colleague Sarah Sigsworth and Prof. Suzanne Munro for patiently editing my English. 


\section{References}

Akatsuka, N. \& Clancy, P.M. 1993. Conditionality and deontic modality in Japanese and Korean: Evidence from the emergence of conditionals. In Southern California Japanese/ Korean Linguistics Conference 2, P.M. Clancy (ed), 177-192. Stanford CA: Japanese/Korean Linguistics.

Asociación de Academias de la Lengua Española \& Real Academia Española. 2009. Nueva gramática de la lengua española. Sintaxis II. Madrid: Espasa.

$\mathrm{Au}$, T.K. 1983. Chinese and English counterfactuals: The Sapir-Whorf hypothesis revisited. Cognition 15: 155-187. doi: 10.1016/0010-0277(83)90038-0

Barceló, G.J. \& Bres, J. 2006. Les temps de l'indicatif en français. Paris: Ophrys.

Bartning, I. 1997. L'apprenant dit avancé et son acquisition d'une langue étrangère. Tour d'horizon et esquisse d'une caractérisation de la variété avancée. Acquisition et Interaction en Langue Etrangère (Aile), 9: 9-50.

Bartning, I. \& Schlyter, S. 2004. Itinéraires acquisitionnels et stades de développement en français L2. Journal of French Language Studies 14(3): 281-299.

doi: 10.1017/So959269504001802

Bates, E. 1976. Language and Context: The Acquisition of Pragmatics. New York NY: Academic Press.

Bernini, G. 1995. Lexical expression of modality in second languages: The case of Italian modal verbs. In From Pragmatics to Syntax. Modality in Second Language Acquisition, A. Giacalone Ramat \& G. Crocco Galéas (eds), 295-318. Tübingen: Günter Narr.

Bernini, G. 1994. Le frasi ipotetiche nell'italiano di stranieri. In Italiano lingua seconda / lingua straniera. Atti del XXVI Congresso. Società di linguistica italiana 34, A. Giacalone Ramat \& M. Vedovelli (eds), 271-296. Rome: Bulzoni.

Bloom, A.H. 1981. The Linguistic Shaping of Thought: A Study in the Impact of Language on Thinking in China and the West. Hillsdale NJ: Lawrence Erlbaum Associates.

Bowerman, M. 1986. First steps in acquiring conditionals. In On Conditionals, E.C. Traugott, A.G. ter Meulen, J.S. Reilly \& C.A. Ferguson (eds), 285-308. Cambridge: CUP. doi: 10.1017/CBO9780511753466.016

Carroll, M., Rossdeutscher, A., Lambert, M. \& von Stutterheim, C. 2008. Subordination in narratives and macrostructural planning. A comparative point of view. In 'Subordination' versus 'Coordination' in Sentence and Text [Studies in Language Companion Series 98], C. Fabricius-Hansen \& W. Ramm (eds), 161-184. Amsterdam: John Benjamins.

doi: 10.1075/slcs.98.09car

Charaudeau, P. 1992. Grammaire du sens et de l'expression. Paris: Hachette.

Chevalier, J.C., Blanche-Benveniste, C., Arrivé, M. \& Peytard, J. 1964. Grammaire du français contemporain. Paris: Larousse.

Chini, M. 1995. Meno male che non elo un topo, se no mi mangia un gatto, pe finta. In From Pragmatics to Syntax. Modality in Second Language Acquisition, A. Giacalone Ramat \& G. Crocco Galèas (eds), 143-172. Tübingen: Narr.

Comrie, B. 1986. Conditionals: A typology. In On Conditionals, E.C. Traugott, A.G. ter Meulen, J.S. Reilly \& C.A. Ferguson (eds), 77-99. Cambridge: CUP. doi: 10.1017/CBO9780511753466.005 
Dimroth, C., Andorno, C., Benazzo, S. \& Verhagen, J. 2010. Given claims about new topics. How Romance and Germanic speakers link changed and maintained information in narrative discourse. Journal of Pragmatics 42: 3328-3344. doi: 10.1016/j.pragma.2010.05.009

Fauconnier, G. 1984. Espaces mentaux: Aspects de la construction du sens dans les langues naturelles. Paris: Editions de Minuit.

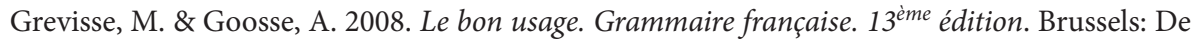
Boeck Duculot.

Harley, B. 1992. Patterns of second language development in French immersion. Journal of French Language Studies 2: 159-183. doi: 10.1017/S0959269500001289

Harris, M.B. 1986. The historical development of si- clauses in Romance. In On Conditionals, E.C. Traugott, A.G. ter Meulen, J.S. Reilly \& C.A. Ferguson (eds), 265-284. Cambridge: CUP. doi: 10.1017/CBO9780511753466.015

Hellberg, G. 1971. Le système hypothétique dans le français écrit et parlé. PhD dissertation, University of Stockholm.

Hendrix, L., Housen, A. \& Pierrard, M. 2001. Connaissances et compétences: L'impact de la grammaire sur le développement des compétences langagières en FLE. In Didactique des langues romanes, le développement de compétences chez l’apprenant, E. Maeder (ed.), 600605. Brussels: De Boeck Université.

Housen, A., Kemps, N., Pierrard, M. 2006. Stades développementaux et contexte instructionnel: L'acquisition de la morphologie verbale chez des apprenants avancés de FLE. Cahiers de l'Institut de Linguistique de Louvain 32: 273-293.

Howard, M. 2012. From tense and aspect to modality: The acquisition of future, conditional and subjunctive morphology in L2 French. A preliminary study. In Tense, Aspect and Mood in First and Second Language Acquisition, E. Labeau \& I. Saddour (eds), 201-223. Amsterdam: Rodopi.

Iatridou, S. 2000. The grammatical ingredients of counterfactuality. Linguistic Inquiry 31: 231270. doi: $10.1162 / 002438900554352$

Kahneman, D. \& Tversky, A. 1982. The simulation heuristic. In Judgment under Uncertainty, D. Kahneman, P. Slovic \& A. Tversky (eds), 201-208. Cambridge: CUP. doi: 10.1017/CBO9780511809477.015

Kahneman, D. \& Miller, D.T. 1986. Norm theory: Comparing reality to its alternatives. Psychological Review 93: 136-153. doi: 10.1037/0033-295X.93.2.136

Katis, D. 1996. The emergence of conditionals in child language: Are they really so late? In On Conditionals Again [Current Issues in Linguistic Theory 143], A. Athanasiadou \& R. Dirven (eds), 335-386. Amsterdam: John Benjamins.

Klein, W. 2009. How Time is Encoded. <http://www.mpi.nl/people/klein-wolfgang/publicationsold-version/fbpubs09/Klein_2009_How_time_is_encoded.pdf> doi: $10.1515 / 9783110199031.39$

Klein, W. \& Dittmar, N. 1979. Developing Grammars. The Acquisition of German Syntax by Foreign Workers. Berlin: Springer.

Klein, W. \& Perdue, C. 1997. The basic variety. Second Language Research 13(4): 301-347. doi: $10.1191 / 026765897666879396$

Klein, W. \& von Stutterheim, C. 2006. How to solve a complex verbal task: Text structure, referential movement and the Quaestio. In Aquisição de línguas estrangeiras, M.R. Brum de Paula \& G. Sanz Espinar (eds), 30/31: 29-67.

Krifka, M. 2012. Modality (and tense) in Daakie (Austronesian, Vanuatu). Oral communication. Max Planck Institute for Psycholinguistics, The Netherlands. 
Mandel, D.R. \& Lehman, D.R. 1996. Counterfactual thinking and ascriptions of cause and preventability. Journal of Personality and Social Psychology 71(3): 450-463. doi: 10.1037/0022-3514.71.3.450

Miller, D.T. \& Gunasegaram, S. 1990. Temporal order and the perceived mutability of events: Implications for blame assignment. Journal of Personality and Social Psychology 59(6): 1111-1118. doi: 10.1037/0022-3514.59.6.1111

Pietrandrea, P. 2010. The conceptual structure of irreality. A focus on non-exclusion-of-factuality as a conceptual and linguistic category. Language Sciences 34(2): 184-199. doi: 10.1016/j.langsci.2011.08.004

Reilly, J.S. 1982. The Acquisition of Conditionals in English. PhD dissertation, University of California, Los Angeles.

Renzi, L. \& Salvi, G. 1991. Grande grammatica italiana di consultazione, Vol. II: I sintagmi verbale, aggettivale, avverbiale. La subordinazione. Bologna: Il Mulino.

Repiso, I. 2013. Parlons de l'irréel. L'expression de la contrefactualité en français, en espagnol et en italien et par des apprenants de français hispanophones et italophones. $\mathrm{PhD}$ dissertation, Aix Marseille University. <http://www.risc.cnrs.fr/mem_theses_pdf/2013_Repiso.pdf>

Riegel, M., Pellat, J.C., \& Rioul, R. 1994. Grammaire méthodique du français. Paris: Presses universitaires de France.

Riegel, M., Pellat, J.C. \& Rioul, R. 2001. Grammaire méthodique du français. Paris: Presses universitaires de France.

Riegel, M., Pellat, J.C. \& Rioul, R. 2014. Grammaire méthodique du français. Paris: Presses universitaires de France.

Schouten, E. 2000. The Role of the Native Language in the Non-Native Acquisition of Hypothetical Conditional Structures. PhD dissertation, The Hague: HAG.

Van linden, A. \& Verstraete, J.C. 2008. The nature and origins of counterfactuality in simple clauses. Cross-linguistic evidence. Journal of Pragmatics 40: 1865-1895. doi: 10.1016/j.pragma.2008.03.008

Verstraete, J.C. 2005. The semantics and pragmatics of composite mood marking: The nonPama-Nyungan languages of northern Australia. Linguistic Typology 9: 223-268. doi: 10.1515/lity.2005.9.2.223

Wells, G.L. \& Gavanski, I. 1989. Mental simulation of causality. Journal of Personality and Social Psychology 56(2): 161-169. doi: 10.1037/0022-3514.56.2.161

Yeh, D. \& Gentner, D. 2005. Reasoning counterfactually in Chinese: Picking up the pieces. In Proceedings of the Twenty-Seventh Annual Meeting of the Cognitive Science Society, 24102415. Mahwah NJ: Lawrence Erlbaum Associates.

\section{Appendix 1}

\section{Stimulus in French}

Karen était assistante à l'édition dans une petite agence de publicité. Elle avait une maladie héréditaire rare, l'hémotrisoma de Karpinson, caractérisée par le manque d'une enzyme qui, normalement, divise certaines protéines du système digestif. En raison de cela les boissons fermentées comme le vin ou les liqueurs pouvaient lui causer de sévères réactions allergiques. 
Karen avait eu une promotion dans son travail et son supérieur, monsieur Carlson, l'avait emmenée dans un restaurant français plutôt cher pour l'y fêter. Etant donné que monsieur Carlson avait mangé plusieurs fois dans ce restaurant il commanda pour les deux. Pendant qu'il regardait le menu il considérait quel plat commander pour Karen. Il pensa d'abord aux coquilles Saint-Jacques mais au dernier moment il choisit les moules marinières. Monsieur Carlson ne le savait pas mais les moules marinières étaient cuites dans une sauce à base de vin tandis que les coquilles Saint-Jacques ne contenaient pas de vin.

Karen savoura son plat mais elle commença à se sentir mal peu après avoir fini. Quelques minutes plus tard elle souffrit de convulsions et elle fut transportée en ambulance. En chemin pour l'hôpital elle mourut.

\section{Stimulus in Italian}

Karen era un'assistente editoriale di una piccola ditta di pubblicità. Aveva una strana malattia ereditaria chiamata emotrisoma di Karpinson, che si caratterizza per la mancanza di un'enzima che normalmente divide certe proteine nell'apparato digerente. Per questo motivo le bevande fermentate come il vino o i liquori potevano causarle gravi reazioni allergiche.

Karen era stata promossa al lavoro e il suo capo, il signor Carlson, l'aveva portata a cena in un ristorante francese piuttosto caro per festeggiare. Siccome il signor Carlson aveva mangiato varie volte in quel ristorante, ordino per entrambi. Mentre guardava il menu, considerava quale piatto ordinare per Karen. Prima penso alle capesante ma all'ultimo momento si decise per le cozze alla marinara. Benché il signor Carlosn non lo sapesse, le cozze alla marinara erano cotte in una salsa a base di vino mentre le pellegrine di San Giacomo non contenevano del vino.

Karen gradi il suo piatto ma incomincio a sentirsi male poco dopo aver finito. In pochi minuti le vennero delle convulsioni e fu soccorsa dall'ambulanza. Karen perse la vita durante il tragitto verso l'ospedale. 